\title{
Miocene transpression effects at the boundary of Central Carpathian Paleogene Basin and Pieniny Klippen Belt: examples from Polish-Slovakian borderland
}

\author{
Mirosław Ludwiniak \\ University of Warsaw, Institute of Geology; ul. Żwirki i Wigury 93, 02-089 Warsaw, Poland; \\ e-mail: Miroslaw.Ludwiniak@uw.edu.pl
}

(C) 2018 Authors. This is an open access publication, which can be used, distributed and reproduced in any medium according to the Creative Commons CC-BY 4.0 License requiring that the original work has been properly cited.

Received: 30 January 2018; accepted: 23 February 2018

\begin{abstract}
A geological structural study has been conducted along the tectonic contact zone of the Central Carpathian Paleogene Basin (CCPB) and Pieniny Klippen Belt ( $\mathrm{PKB})$ in the eastern Podhale and western Spišska Magura areas. It concerned mostly the Central Carpathian Paleogene flysch strata and, to a lesser degree, the Upper Cretaceous rocks of the PKB. Tectonic deformation structures genetically related to the important tectonic boundary in question occur within a c. 1.5-2 km-wide strip of the Paleogene flysch rocks adjacent from the south to the PKB. Two parallel structural domains have been distinguished within this strip: the contact zone proper in the north and the peri-Pieniny monocline in the south. Most of the minor faults documented in the Paleogene flysch bear a record of dextral motion parallel to the contact zone. Some dextral-reverse oblique slip faults of NE-SW and W-E trends have also been recognized. Discrepancies in the orientation and sense of movement on strike-slip faults in the Paleogene flysch rocks and those in marlstones of the "klippen envelope" of the PKB-were encountered. They probably reflect differences in the structural history of both the adjacent rock complexes, as the Upper Cretaceous deposits of the PKB must have experienced more deformation events and, in general, were affected by much more intense strain than those of the ССРВ. Contractional structures, such as south-vergent reverse faults and recumbent folds which point to ca N-S tectonic shortening, have also been found in the Paleogene rocks. The entirety of the structural features found in the $\mathrm{C} C P B$ is characteristic of a transpressional regime. The regionally consistent coexistence of structures resulting from strike-slip movements and tectonic shortening, as well as features pointing directly to a transpressional regime, prove the transpressional dextral nature of the contact between the CCPB and PKB.
\end{abstract}

Keywords: structural geology, tectonics, Western Central Carpathians, Podhale Basin, Spišska Magura, faults, folds, joints, calcite veins

\section{INTRODUCTION}

The significance of strike-slip tectonics and the role it plays in various tectonic settings has become increasingly recognized over the last sixty years (see e.g. Moody \& Hill 1956, Sylvester 1988, Woodcock \& Schubert 1994). Its role in the formation of most orogenic belts has also become better known (see e.g. Şengör 1990, Hubbard 1999, Storti et al. 2003, Cunningham \& Mann 2007, Morley et al. 2009), not excluding the Carpathian orogen (for a review see Marko 2015). Convergence slip vectors are usually not exactly orthogonal to plate boundaries or intraplate deformation zones, which implies strike-slip faulting active in obliquely convergent settings (e.g. Molnar 1992, 
Dewey et al. 1998). Deformation zones of various scales and nature form in transpressional regimes (e.g. Molnar \& Tapponier 1975, Qu \& Zhang 1994, Cunningham et al. 1996, 2003, Buslov et al. 2003, Lacquement et al. 2005, Konon et al. 2016). In the upper crust they are commonly represented by strike-slip fault systems, accompanied by a wide spectrum of related structures.

Strike-slip motions on the Outer and Central Carpathians boundary have been considered for decades in the context of the PKB and Magura Nappe contact area (e.g. Birkenmajer 1983, 1985, Aleksandowski 1985, 1989, Jurewicz 1997, 2005, 2018). Paleomagnetic studies have also brought contributions shedding some light on this problem (e.g. Kruczyk et al. 1992, Márton \& Fodor 1995, Márton et al. 1999, 2013, 2016, Grabowski et al. 2006). Structural studies of the contact zone between the PKB and Central Carpathians have mainly concerned the Paleogene basin succession of the latter (e.g. Mastella 1975, Mastella et al. 1988, Ratschbacher et al. 1993, Plašienka et al. 1998).

Detailed recognition of the structural characteristics of the PKB boundaries is important for the better comprehension of the nature of the contact zone between the Outer and Central Carpathians and, hence, for a better understanding of Neogene tectonic history and the evolution of the Western Carpathians. The purpose of this paper is to present and analyze structural manifestations of the Miocene transpression at the tectonic contact of the Podhale Synclinorium and the PKB in Podhale and Spiš areas (Poland and Slovakia borderland; Fig. 1). Particular attention is paid here to field examples of structural phenomena from the area between the Niedzica village in the west and the Stráňany village in the east (Fig. 1C, D).

\section{GENERAL TECTONIC SETTING}

The Central Western Carpathians (CWC), located south of the Pieniny Klippen Belt (PKB), are composed of several crustal superunits affected by Alpine, mostly Cretaceous, thick-skinned thrust tectonics. The superunits comprise a pre-Alpine, mostly Paleozoic, crystalline basement and its Permo-Mesozoic autochthonous sedimentary cover, partly detached and involved in thinskinned cover nappes overthrust to the north (in the present-day coordinates) during the Late
Cretaceous (e.g. Andrusov 1965, Plašienka et al. 1997, Froitzheim et al. 2008). In the area under consideration, the CWC thrust units are covered by the Paleogene-lowermost Miocene Podhale Flysch (Fusán et al. 1967, Marschalko 1968).

\section{Pieniny Klippen Belt (PKB)}

The Pieniny Klippen Belt is a narrow, discontinuous, strongly tectonized belt, c. $600 \mathrm{~km}$ long, which parallels the Carpathian arc from the Vienna Basin's northern edge to the Maramureș land, in the Romania-Ukraine borderland (Fig. 1A). This peculiar, up to $20 \mathrm{~km}$-wide structure is composed mainly of Jurassic-Lower Cretaceous limestones and marlstones and of Upper Cretaceous-Paleogene shales, marls, and flyschoid rocks. The PKB sedimentary complex includes several successions of Early Jurassic-Paleogene strata with strongly variable lithology (e.g. Andrusov 1938, Birkenmajer 1960b, Mišík 1994, Golonka \& Krobicki 2001, 2004), deformed during several tectonic events between the Late Cretaceous and Miocene (e.g. Birkenmajer 1986). The boundaries of the PKB are of a tectonic nature and, north of the Tatra Mts., are represented by large-scale faults with a significant Cenozoic strike-slip component (e.g. Kováč \& Hók 1996, Plašienka 2011), which, together with the accompanying faults, render the PKB a positive flower structure-like geometrical characteristics. The latter is mostly an effect of strata steepening and PKB belt narrowing during the post-Paleogene dextral transpression (e.g. Ratschbacher et al. 1993, Plašienka et al. 2008, Plašienka \& Mikuš 2010).

The multistage deformed, lithologically contrasted Jurassic-Paleogene PKB sedimentary successions are reflected in the recent, distinctive geomorphology of this area, with variously sized blocks of weathering-resistant Jurassic-Lower Cretaceous rocks forming highly elevated, commonly isolated klippen that are embedded in less resistant Upper Cretaceous-Paleogene deposits of the so-called "klippen envelope".

The PKB is interpreted as an expression of a suture zone which separates the Outer Carpathians from the Central Carpathians or, in a wider context, as a structure genetically related to the suture between the North European plate and the Alcapa terrane (e.g. Royden 1988, Csontos et al. 1992, Kováč et al. 1993, 1998, Plašienka et al. 1997, Fodor et al. 1999, Zoetemeijer et al. 1999). 

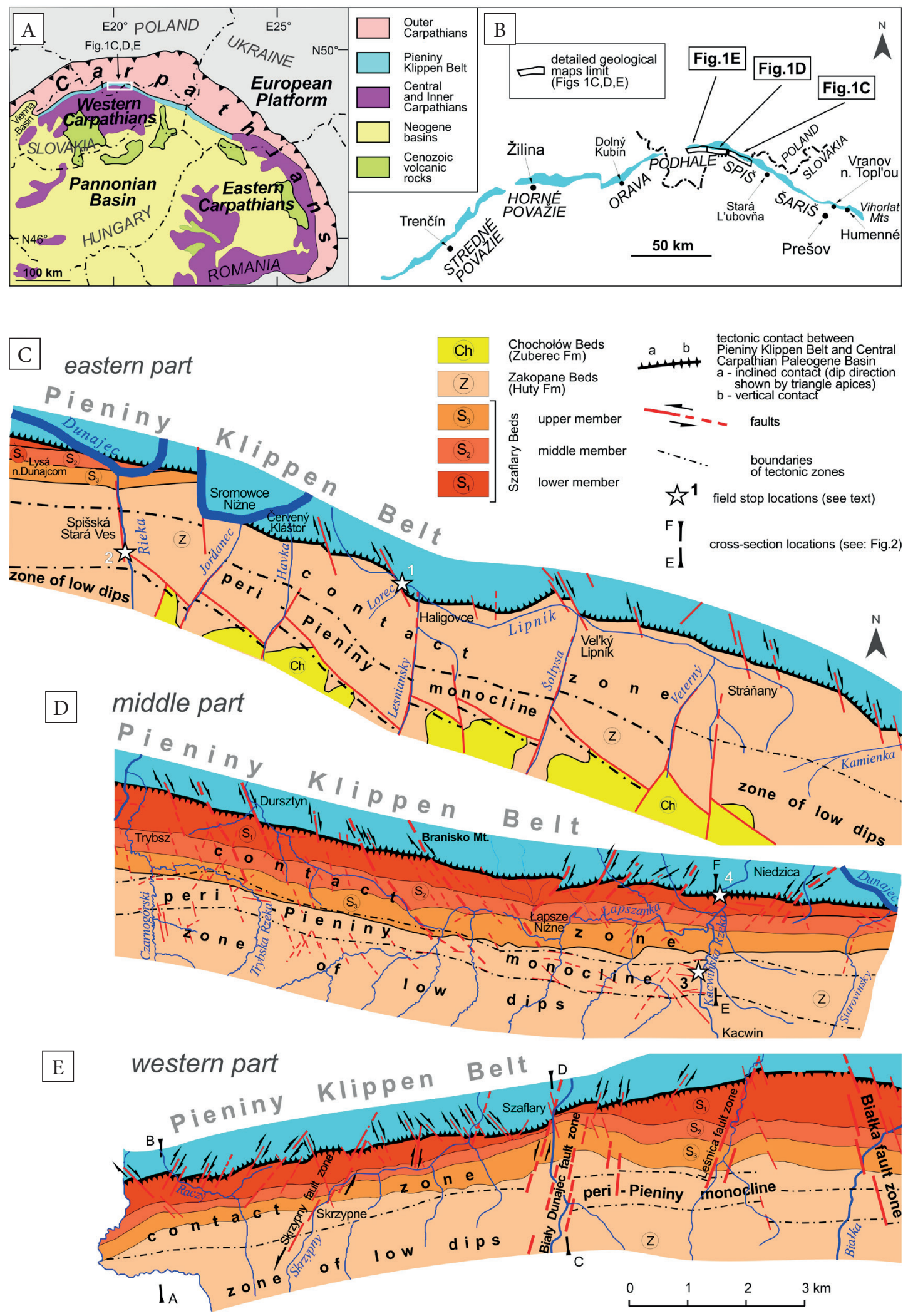

Fig. 1. Position of the study area in the Carpathian-Pannonian region (after Picha 1996, modified) (A). Position of the study area against the background of the Pieniny Klippen Belt trend (B). Simplified geological map of the contact zone between the Pieniny Klippen Belt and Central Carpathian Paleogene Basin in the Podhale-Spišska Magura area with the location of field session stops (based on Mastella et al. 1988, 2012, Janočko et al. 2000 and the author's own investigations) (C-E) 
The PKB and Outer Carpathian nappes were both integrated into a Cenozoic accretionary prism at the front of the Alcapa terrane, overriding the North European plate during the Early to Middle Miocene times (Oszczypko \& Ślączka 1989; see also Ślączka 1996a, 1996b, Golonka et al. 2000).

\section{Central Carpathian Paleogene Basin (CCPB)}

The Mesozoic and older rocks of the Central Western Carpathians involved in the Late Cretaceous nappes became discordantly covered by Paleogene clastic deposits that formed the Central Carpathian Paleogene Basin (CCPB; Fusán et al. 1967, Marschalko 1968, Soták et al. 2001). At present, the Paleogene deposits are preserved in morphological depressions separating the several elevated mountainous massifs that expose the Mesozoic nappe structure of the CWC. The CCPB fill consists mostly of deep-water turbidites (with a recently preserved total thickness reaching up to $3500-4500 \mathrm{~m}$ ), underlain by calcareous, transgressive Eocene deposits (with a thickness ranging between $0 \mathrm{~m}$ and c. $350 \mathrm{~m}$ ).

The CCPB sedimentary succession has been subdivided into several formal lithostratigraphic members, referred to as the Podtatranska Group in Slovakia (Gross et al. 1984), and into informal stratigraphic units in Poland (collectively named the Podhale Flysch; Watycha 1968). The lowermost, laterally discontinuous calcareous deposits, Middle to Late Eocene in age, which represent the so called "Nummulite Eocene", are formally ascribed to the Borové Fm. (Roniewicz 1969, Gross et al. 1984). An overlying, turbiditic flyschoidal sequence has been dated to the Oligocene-Earliest Miocene (Olszewska \& Wieczorek 1998, Gedl 2000, Garecka 2005). Its lowermost, sandstone-conglomerate member, named the Szaflary Beds (or Šambron Beds sensu Chmelík 1957), crops out in the northernmost part of the CCPB. Lying above them are the Zakopane Beds (Huty Fm.) comprised predominantly of thin-bedded claystones and mudstones with minor intercalations of thin-bedded sandstones. The intercalations of thin- to medium-bedded sandstones are more numerous in the upper part of this member.
The succeeding Chochołów Beds (Zuberec Fm.) contain medium- and thin-bedded sandstones, mudstones and claystones interbedded with numerous thick-bedded sandstones. In the upper part of this formation, complexes of sandstones and claystones are intercalated by several thick sandstone beds. The Ostrysz Beds define the uppermost member of the Podhale Flysch. In the Polish segment of the CCPB it is preserved only at the top part of the Ostrysz Mountain. Their equivalent in Slovakia is the Biely Potok Fm., composed of thin- to thick-bedded sandstones, mudstones and claystones.

The CCPB formation and evolution were probably controlled by crustal thinning or subcrustal erosion (e.g. Kázmér et al. 2003). An extensional collapse of the overthickened CWC crust may have been coupled with a slab-pull due to retreating subduction of the intra-Carpathian oceanic lithosphere (see Plašienka \& Soták 2015, Kováč et al. 2016).

\section{PODHALE SYNCLINORIUM (PS)}

The CCPB in its Orava-Podhale-Spiš sector is currently represented by the $10-16 \mathrm{~km}$-wide, E-W-elongated, asymmetrical Podhale Synclinorium (PS; Halicki 1963, Watycha 1968). Its structure has been customarily described, using local informal names referring to several W-E-trending domains, the latter defined on the basis of their various distinctive features (e.g. Mastella 1975, Ludwiniak 2006, 2010). From north to the south these are (Figs. 1C-E, 2):

- zone of contact between the PS and PKB,

- peri-Pieniny monocline,

- zone of low dips of strata,

- Synclinorium axial zone,

- Synclinorium southern limb,

- peri-Tatric zone.

The latter E-W structural domains are cut by several transverse and diagonal fault zones, such as those of Krowiarki, Biały Dunajec, Białka and smaller ones, of Jelešňa, Skrzypny and Rieka (Mastella et al. 1988, 1996, 2012, Bac-Moszaszwili 1993, Ludwiniak \& Rybak-Ostrowska 2010). 

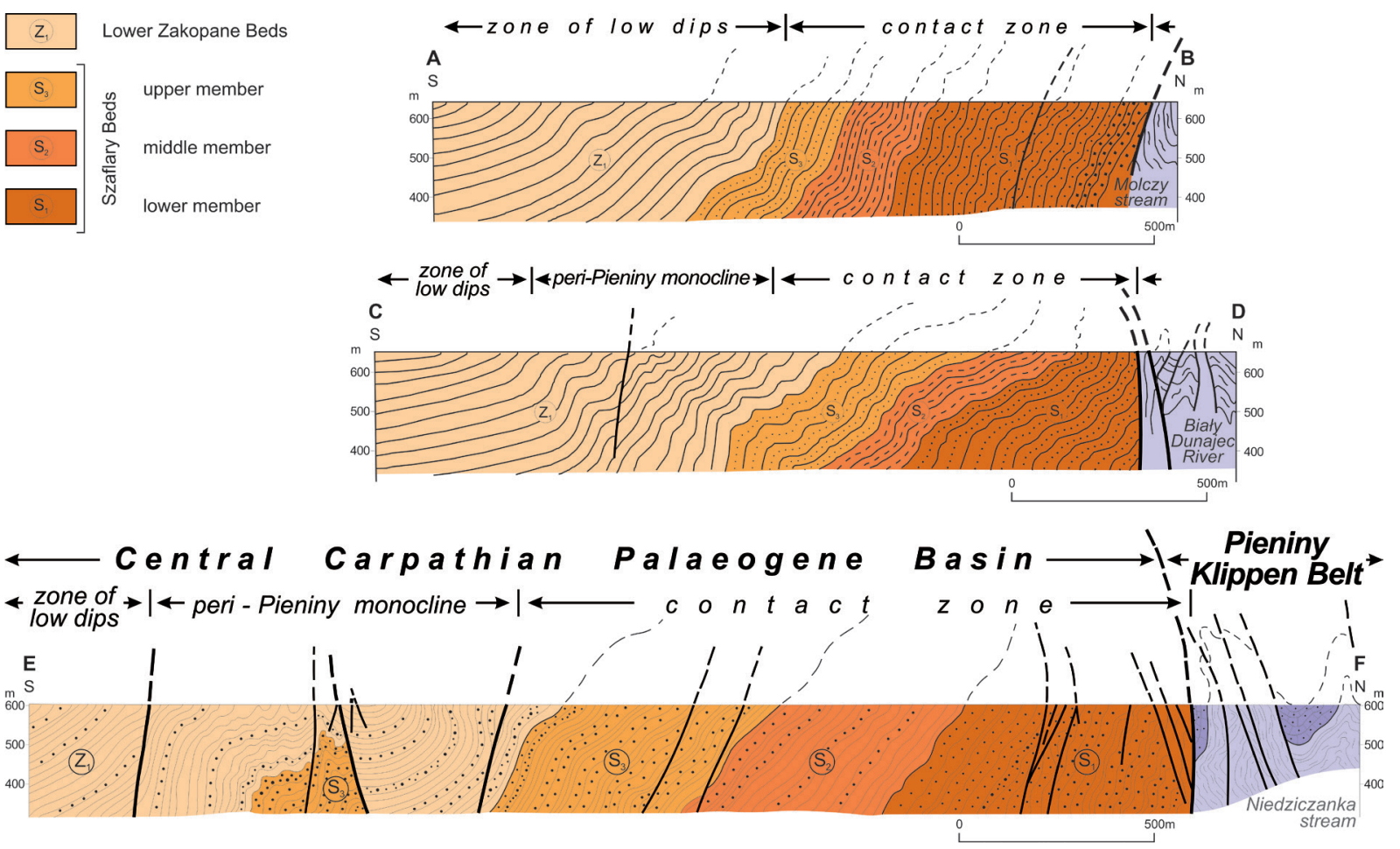

Fig. 2. Geological cross-sections through the contact zone between the Pieniny Klippen Belt and Central Carpathian Paleogene Basin (for location see Figure 1D, E; cross-sections A-B and C-D after Mastella et al. 1988, modified; cross-section E-F after Ludwiniak et al. 2009, modified)

\section{CONTACT \\ OF THE PODHALE SYNCLINORIUM AND PIENINY KLIPPEN BELT}

As a whole, the CCPB sedimentary fill is rather weakly or moderately deformed. Zones of more intense tectonic deformation are predominantly related to basement-rooted fault zones which have significant influence on the structural style of flysch rocks (whose basement are Mesozoic rocks of the Križña Nappe). The most intense CCPB flysch deformation is restricted to a $1.5-2 \mathrm{~km}$-wide zone adjacent to the PKB. The tectonic contact between the PKB and PS (Uhlig 1897, 1903) is represented by a deep-seated, steep fault zone (Birkenmajer 1958, 1960a, 1964, Mastella 1975, Mastella et al. 1988, Ludwiniak 2010). To the west, in the Orava segment, the CСРB deposits are overthrust by Mesozoic PKB rocks (Gross et al. 1993). The PKB is backthrust over the CCPB rocks also still farther to the west. The dip of the PKB/CCPB contact ranges between $30-45^{\circ} \mathrm{N}$ near Žilina (Picha et al. 2006). Similarly, to the east, in the Spiš sector, the contact dips to the north, usually at a moderate angle (ca. $50^{\circ} \mathrm{N}$; Nemčok 1990, Plašienka 2012). Such a NE-inclined attitude of the PKB southern boundary continues farther eastward in the Šariš area. Still somewhat further east, between Prešov and Vranov $n$. Topl'ou, the attitude of the PKB contact is again vertical and somewhat further eastward, near Humenne, the PKB southern boundary becomes NE-dipping again (Pospišil \& Filo 1982).

Relatively high positive temperature anomalies above the contact of the PKB and CCPB have been recorded in easternmost Podhale (Pomianowski 1988).

The distance of the PKB backthrusting over the Central Carpathian thrust units below the CCPB fill is estimated at a few kilometers. However, the backward tectonic transport of the PKB, together with the innermost part of the Magura Nappe, is estimated from seismic profiles as no less than $12 \mathrm{~km}$ in the Orava-Horné Považie region (Picha et al. 2006).

In the easternmost part of the CCPB Spiš sector adjoining the $\mathrm{PKB}$, a complicated, slightly 
south-vergent antiformal structure, the Šambron-Kamenica zone, is located. It comprises strongly deformed, thin-bedded, shaly flysch with large conglomerate bodies (the Upper Eocene-Lower Oligocene Šambron Beds), which are not quite identical with the lower part of the CCPB fill (Szaflary Beds). The Šambron-Kamenica zone and the PKB are separated by an oblique dextral-reverse fault (Plašienka 1998). However, the rocks of the Šambron-Kamenica zone show only weak effects of dextral transpression (Plašienka et al. 1998). Instead, they display a high value of tectonic shortening reaching even 50\% (Plašienka \& Soták 1999). The southerly vergence of the Šambron-Kamenica antiformal stack is an effect of the PKB backthrusting onto the $\mathrm{CCPB}$. An occurrence of serpentinite and spinel detritus in its sandstones points to their likely deposition in a perisutural basin (Soták \& Bebej 1996). This is the premise for the interpretation that the CCPB and PKB contact follows a suture zone related to the Oligocene to Miocene (until $17 \mathrm{Ma}$; Decker \& Peresson 1996) collision.

The PKB/CCPB contact is poorly exposed. It can be studied at few natural outcrops and is hardly ever uncovered in ephemeric, artificial exposures (Plašienka et al. 2013). The limited number of outcrops is commonly due to the finegrained and fine-bedded characteristics of the lower flysch series of the CCPB (Lower Zakopane or Szaflary Beds) that are in direct contact with the marly and shaly rocks of the "klippen envelope" of the PKB. They are both characterized by weak resistance to weathering. Moreover, in some sectors of the Western Carpathians, the PKB and its contact zone with the CCPB are subsided and covered by younger, late- to postorogenic deposits (i.e. the Orava-Nowy Targ Basin, the Plaveč graben, area between Drienica and Terňa northwest from Prešov) or hidden below Neogene volcanics (Vihorlat Mts. area). In its turn, in eastern Slovakia, between Demjata and Humenne, there is no possibility to directly observe the contact zone due to weakly differentiated terrain morphology developed on weak Late Albian-Early Maastrichtian rocks representing this sector of the PKB (marlstones and silty marlstones with rare sandstones, claystones, polymict conglomerates and thin bedded flysch). It is, therefore, the Podhale and Spiš area that offers a relatively good opportunity for studying the contact zone under consideration.
In Podhale and Spiš, the contact of the PKB and $\mathrm{CCPB}$ is a narrow zone of intense faulting and widespread occurrence of cataclastic and/or tectonically brecciated rocks. The Upper Cretaceous rock series of the PKB "klippen envelope", being mostly in direct contact with the flysch of the CCPB, is, in general, more deformed than the latter, as it had also been influenced by older deformation episodes. It is significant that the trend of some map-scale fold axes in the PKB is clearly oblique, whereas the CCPB flysch beds and fold axes in them strike usually parallel to the contact line. A $20-35^{\circ}$ anticlockwise discrepancy of the fold axes' trend relative to the contact can be observed between Łapsze Niżne and Vel'ký Lipník (Birkenmajer 1958, 1960a, Mastella 1972, Janočko et al. 2000).

The strongest effects of tectonic deformation on the southern side of the contact within the CCPB are limited to a dozen to several dozen meters-wide zone directly adjoining it. This zone contains steeply dipping faults, roughly parallel to the contact line, as well as abundant cataclastic and brecciated rocks. The faults often show a significant dip-slip component. They are dipping both north and south, with their southern sides downthrown. Some of them developed a few to several dozen-wide bands of fault rocks. Calcareous tufa deposits occur frequently in close proximity. The beds are steeply dipping to the south, and locally achieve a vertical or overturned position.

The PKB/CCPB contact itself, as well as the adjoining CCPB flysch rocks, are also cut by numerous transverse and oblique faults of various dimensions. Map-scale faults that offset the contact line are NNW-SSE and NE-SW-trending. The NE-SWtrending ones dominate between Łapsze Niżne and Niedzica (Fig. 1D). The attitude of the latter faults, considered as kinematically related to the major strike-slip displacement on the Southern Pieniny Fault (named the Podhale Fault by Plašienka et al. 2013 and Jurewicz 2018), is consistent with the sinistral sense of that displacement, anticipated from regional considerations. This is, however, at odds with the dextral sense interpreted from mesoscopic structures in the field. Perhaps this discrepancy is the results of the opposite sense of movement along the $\mathrm{PKB} / \mathrm{CCPB}$ contact during the earlier, regional-scale sinistral event (cf. e.g. Royden et al. 1982, 1983, Aleksandrowski 1985, 1989, Royden 1988). It is worthy of note that on the northern margin of 
the PKB between villages of Czorsztyn and Jawor$\mathrm{ki}$, within a contact zone with the Magura Nappe, map-scale and mesoscopic strike-slip faults have been documented (Birkenmajer 1983, 1985). They are NW-SE-trending dextral and NNE-SSWtrending sinistral faults, as well as NNW-SSE dextral and/or sinistral ones. Their occurrence suggest that they are related to the strike-slip motion along the principal Northern Pieniny Fault. The attitude and kinematics of these faults suggest they are effects of more than one strike-slip episode, characterized by the opposite sense of movement (dextral and sinistral) along the principal fault. A reactivation of some faults during a younger episode cannot also be excluded. Another likely explanation is that those map-scale faults cutting the $\mathrm{PKB} / \mathrm{CCPB}$ contact, or at least some of them, were reactivated as dip-slip faults. Thus, in this case, the apparent "strike-slip" displacement may be misleading and should be treated rather as the "strike-separation" only (see Śmigielski et al. 2011; in other words: the seemingly "strike-slip" characteristic of these faults may be explained by an intersection effect between the north-inclined contact and a dip-slip transverse fault).

\section{Mesofaults}

The entire population of mesoscale faults cutting the CСPB flysch rocks within the contact zone is dominated by strike-slip, predominantly dextral faults, oriented more or less parallel to the contact line (whose direction is gradually changing in the Orava-Podhale-Spiš sector of the Western Carpathians) (Figs. 1C-E, 3). These faults are often accompanied by drag folds (Fig. 4).

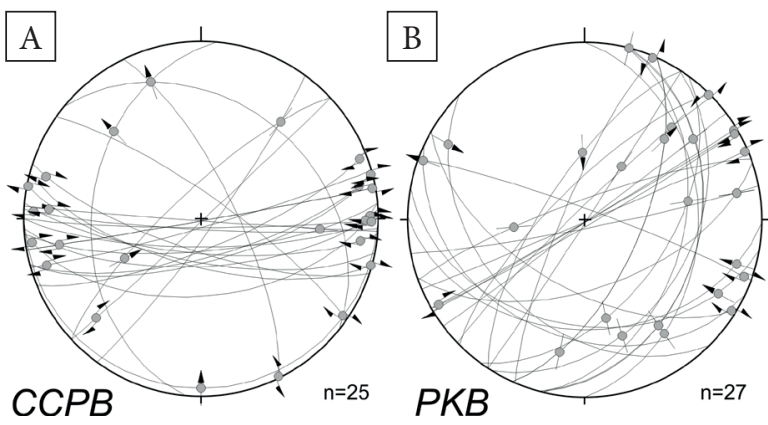

Fig. 3. Kinematics of minor faults (shown on Angelier's diagrams) in the flysch rocks of the CCPB Szaflary Beds (A) and marlstones (Cenomanian-Turonian) of the PKB Czorsztyn Succession (B). All measurements have been made in Niedziczanka stream channel (field-session stop 4)
Mesoscale strike-slip faults of different orientation are less numerous. They are mostly interpreted as lower-order faults kinematically linked to those parallel to the main dislocation. The less numerous longitudinal, south-dipping reverse mesofaults point to the N-S (NNE-SSW)-directed tectonic shortening perpendicular to the contact line.

A more complex configuration of the fault network occurs where the transverse map-scale fault zones cut the contact zone (Fig. 1C-E). Besides those mentioned above, there are also many mesoscopic faults that are parallel to the transverse zones and they almost always dip steeply to the east (or to the ESE). They have been classified in two groups: of normal and reverse faults (Fig. 5). It is peculiar that these inverse faults are steeper (their dips are generally c. $50-75^{\circ}$ ) than the normal faults (c. 25-45) (Fig. 5). A reactivation of both groups of faults can be considered as a possible explanation of such geometry and kinematics. Originally steep strike-slip faults were probably reactivated as reverse ones. In turn, low dipping faults could be developed as small thrusts and reactivated as normal faults and thus we are dealing with inverted faults.

The orientation and geometry of the transverse, reverse mesofaults suggest they may have been related to and partly accommodate the strain effects of the dextral motion along the $\mathrm{PKB} / \mathrm{CCPB}$ contact. It is also supposed that the transverse, normal, low-angle mesofaults are younger than the normal high-angle ones and must have developed during the uplift of the CCPB and PKB. However, their unusually low dips do not allow the possibility that they have played the role of structures partly compensating for the dextral movement along the contact to be excluded.

Some dextral displacement within the contact zone is transferred by bedding-parallel slip. Such a displacement mode is not or hardly recognizable, nevertheless few cases of evidence have been documented (e.g. bedding-parallel slickensides and interbed drag-folds - Fig. 6).

In comparison to that in the $\mathrm{CCPB}$, the mesoscale fault network in the Upper Cretaceous rocks of $\mathrm{PKB}$ near to the contact zone is more complex. In the PKB rocks there are several groups of differently oriented mesofaults of distinct kinematic characteristics (Figs. 3B, 7). 

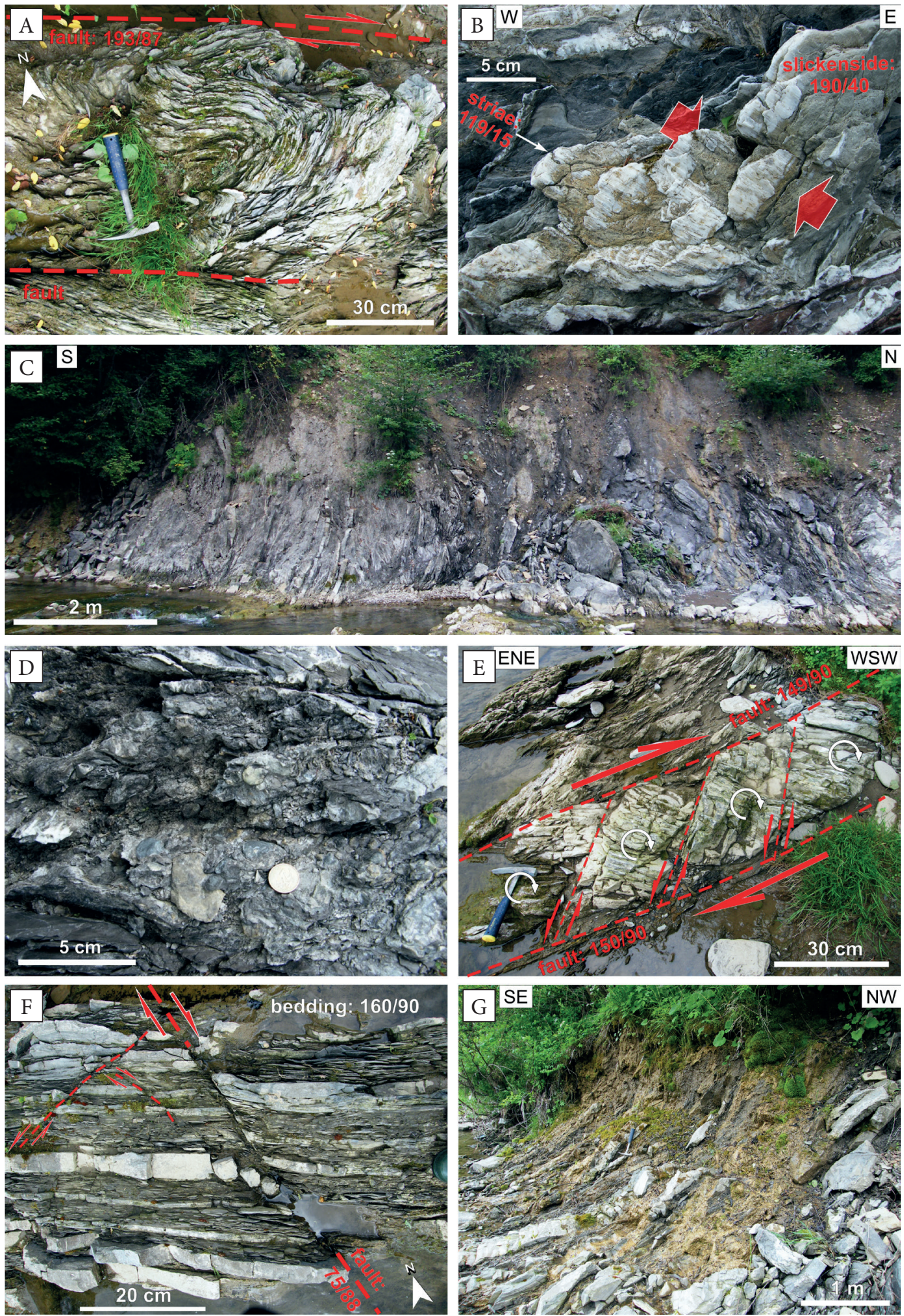

Fig. 4. Tectonic structures in the rocks of the PKB in the tectonic contact zone between the PKB and CCPB (Niedziczanka stream channel, Niedzica village, northern part of the field session stop 4): A) Minor fault-related vertical drag folds. B) Slickenside on the surface of a minor oblique-slip fault. C) Zone of highly deformed rocks in the direct proximity of tectonic contact. D) Cataclastic and brecciated siltstones and mudstones of the Szaflary Beds. Several centimeter-size clasts of thin-bedded sandstones are visible. E) A domino-like structure between two parallel dextral faults; F) Minor dextral fault in thin-bedded flysch rocks. The effects of fault drag accompanied by fragmentation of the thin sandstone layer. G) Stream escarpment coated by the remnants of calcareous tufa. A, B, E-Czorsztyn Succession; $C, D, F$ - the CCPB Szaflary Beds 


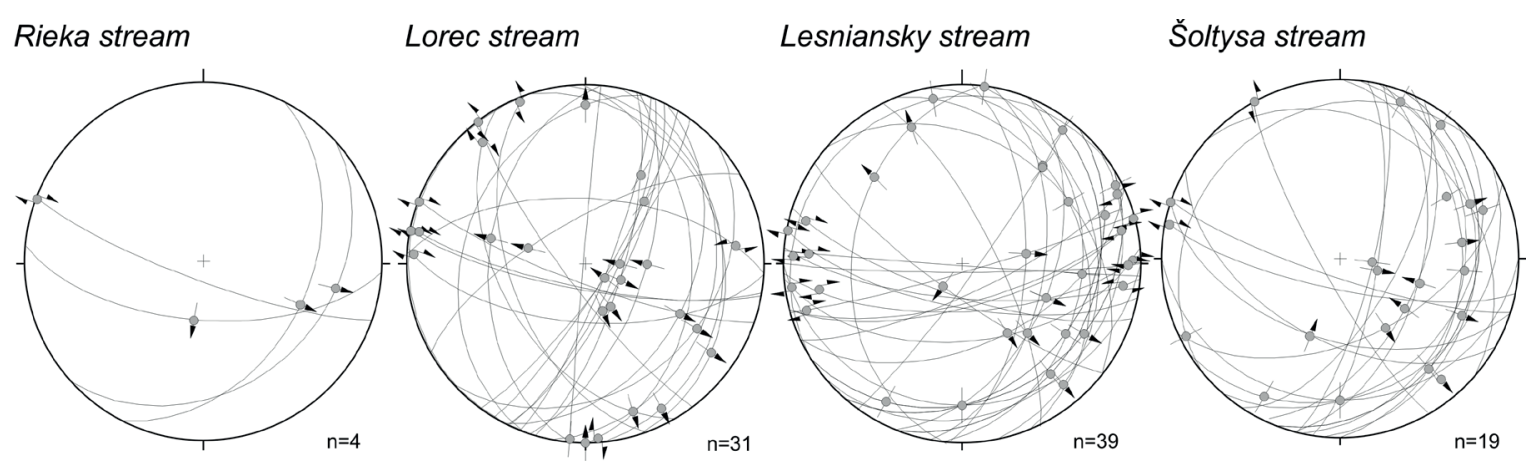

Fig. 5. Kinematics of minor faults (shown on Angelier's diagrams) in the flysch rocks of the Huty Fm. (CCPB) in transversal zones between Spišká Stará Ves village and Vel'ký Lipník village (for location see Figure 1C)
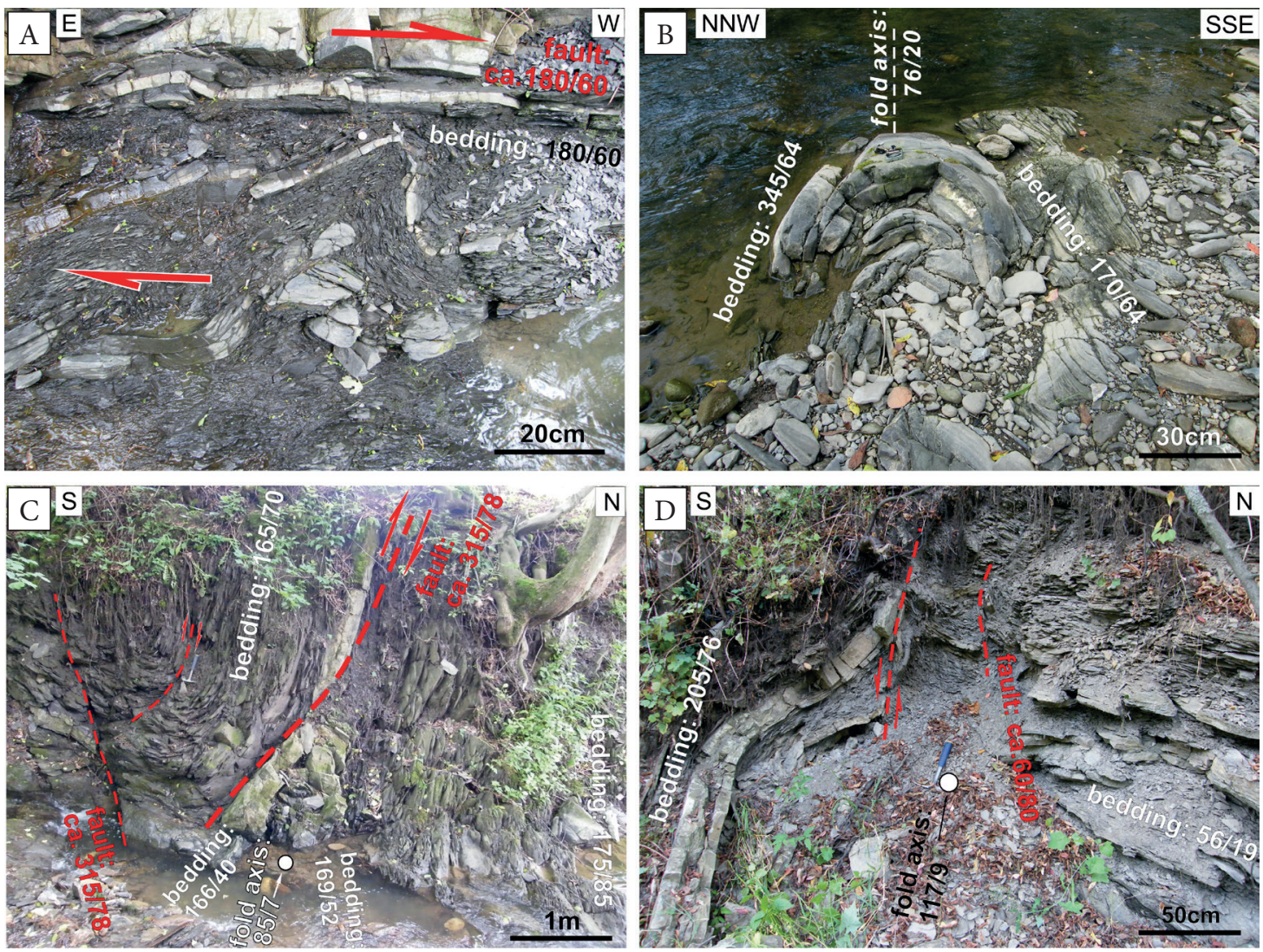

Fig. 6. Meso-scale folds in the zone of contact between the Pieniny Klippen Belt and the Central Carpathian Paleogene Basin. All examples are taken from the Huty Fm. (CCPB): A) small drag-folds related to bedding-parallel slip - example from the Rovne stream in the north-eastern edge of Vel'ký Lipník village (view looking downward); B) minor concentric fold-example from the Lipník stream, between Haligovce and Vel'ký Lipník village; C) folds and accompanying reverse faults - example from the Lipník stream channel on the eastern edge of Stráñany village; D) fold of a box-like shape - an example from the Lipník stream, between Haligovce and Vel'ký Lipník village. The fold core is cut by fold-accommodation faults

Most strike-slip mesofaults can be divided into two groups. The first one includes ENEWSW- (to NE-SW)-trending dextral as well as sinistral faults. Their mutually opposite sense of displacement may suggest they may have possibly developed during more than one tectonic episode.
It is also possible that some of them were reactivated as feather (pinnate) joints by dextral motion along the $\mathrm{CCPB} / \mathrm{PKB}$ contact. It is noteworthy that the mesofaults of this group are subparallel to the map-scale folds mentioned earlier, embracing the Upper Cretaceous rocks. 

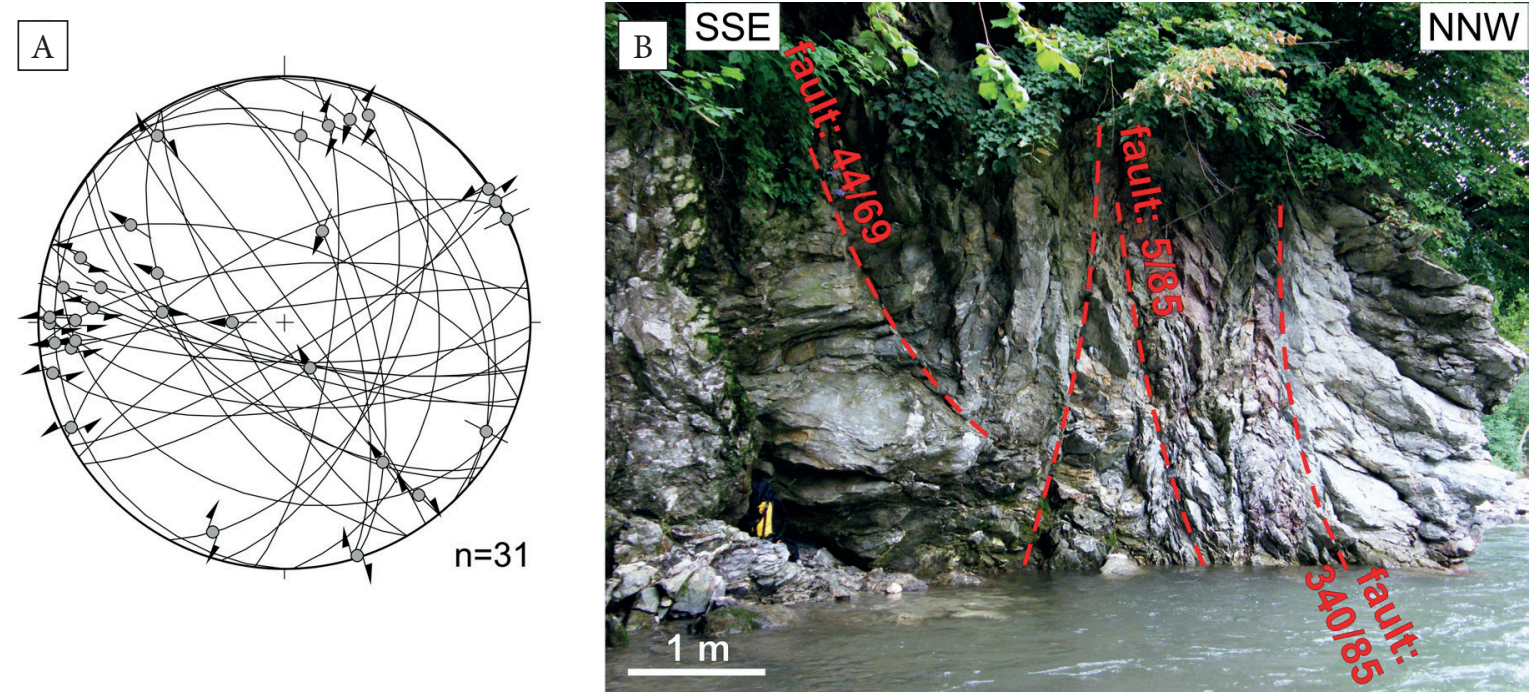

Fig. 7. Intense faulting and shearing, mostly of strike-slip kinematics, in Upper Cretaceous marlstones (Lipník stream channel, Haligovce village, Púchov Fm.; field session stop 1); (A) - Angelier's diagram of minor faults from this outcrop

The second group comprises ESE-WNW- (to E-W)-trending strike-slip mesofaults with the mutually opposite sense of movement - dextral and sinistral ones. These mesofaults are probably younger than those of the first group. It cannot be excluded, however that pre-existing joints could be subsequently slightly strike-slip faulted (faulted joints - see e.g. Marin-Lechado et al. 2004) at different times, in response to the then paleostress fields.

Apart from the strike-slip mesofaults described above, reverse oblique-slip faults have also been recognized in both the $\mathrm{PKB}$ and $\mathrm{CCPB}$ (Figs. 4B, 8A). An occurrence of both the kinematic fault types is considered as expected in view of the transpressive nature of the $\mathrm{CCPB} / \mathrm{PKB}$ contact zone (see e.g. Martínez-Díaz 2002).

\section{Folds}

Most of the studied mesofolds within the CCPB rocks are drag-folds with steeply plunging axes, related to strike-slip mesoscopic faults. Two groups of mesofolds with horizontal and gently plunging axes have also been recognized. The first group embraces longitudinal (i.e. parallel to the CCPB/ PKB contact), ENE-WSW- (to ESE-WNW)-trending, predominantly concentric (Fig. 6B), open to close, less often tight, folds, which are 1B-class (parallel) or 1C-class ones (sensu Ramsay 1967;
Fig. 6C). They are usually upright and steeply inclined (sensu Fleuty 1964; i.e. folds with c. horizontal axis and c. vertical axial surface and folds with c. horizontal axis and axial surface dipping at c. $60-80^{\circ}$, respectively) south vergent folds. The less frequent south vergent gently inclined and recumbent mesofolds are almost always directly associated with north-dipping reverse faults (which are fold-accommodation faults developed following the fold-locking, i.e. in consequence of no possibility of folding progress). Folds of a boxlike shape with fold-accommodation faults in the hinge zones also occur (Fig. 6D). All of them are interpreted here as buckle folds related to the tectonic shortening of the flysch rocks, which had a significantly higher value in the $\mathrm{PKB} / \mathrm{CCPB}$ contact zone than outside it. The second group embraces c. N-S oriented, transverse, gentle, less often open, upright and steeply inclined mesofolds with horizontal or gently plunging axes. They are interpreted here as folds resulting from faultdrag, related to the strike-slip motion along the $\mathrm{PKB} / \mathrm{CCPB}$ contact.

\section{Veins}

An analysis of systematic joints and mineral veins has been conducted between Haligovce and Stráňany (Fig. 9). Its results indicate that almost all of the widest open fractures ( $>1 \mathrm{~cm}$ wide), filled with calcite 

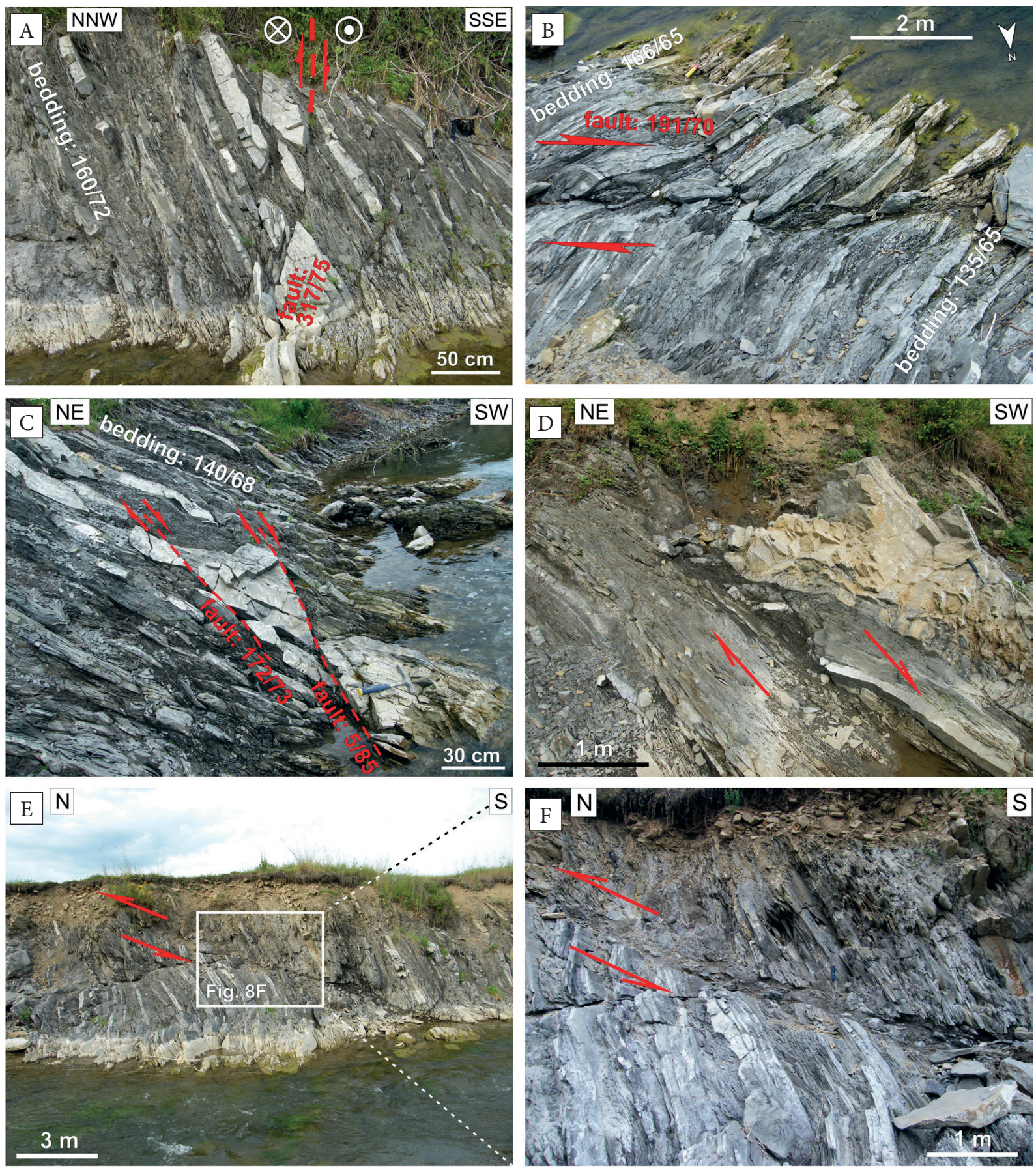

Fig. 8. Mesoscopic faults in the Szaflary Beds (Niedziczanka stream channel, Niedzica village; southern part of the field trip stop 4): A) oblique faults with readable dextral and reverse components of displacement; $B$ ) dextral faults subparallel to the contact line, showing the effects of fault drag (view from the meadow above); C) dextral faults approximately parallel to the contact line; D) intensely fractured thick-bedded sandstone layer visible on the southern side of a dextral fault; E), F) low-angle thrust with top-to-the-north sense of displacement

veins, are NNW-SSE to N-S striking (Fig. 9A-D). This tendency can be observed both in the CCPB and the Upper Cretaceous rocks of the PKB (Fig. 9A, B). Their spatial setting with respect to the mean general direction of the $\mathrm{CCPB} / \mathrm{PKB}$ contact line is typical of the extensional fractures developed within dextral strike-slip zone under simple shear or/and transpression conditions (Ramsay 1967; Fig. 9E). 
A

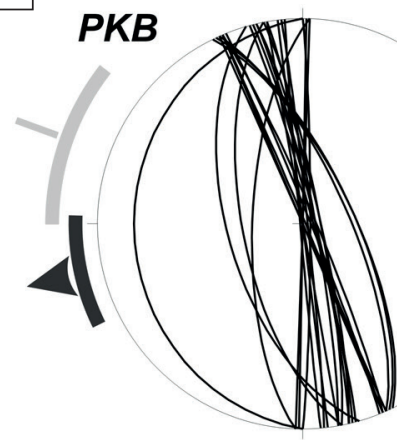

B

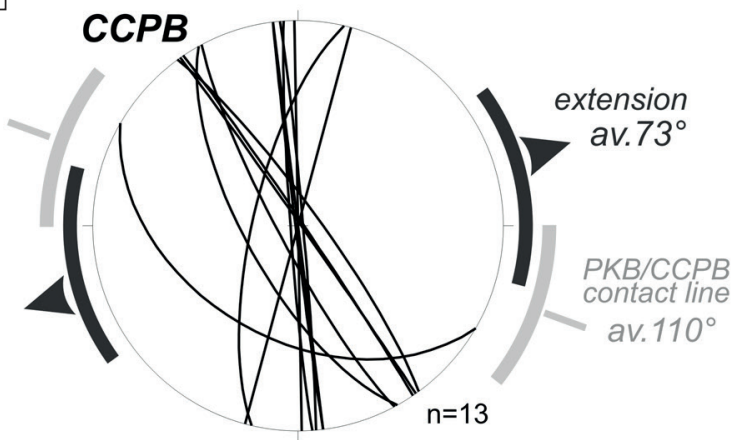

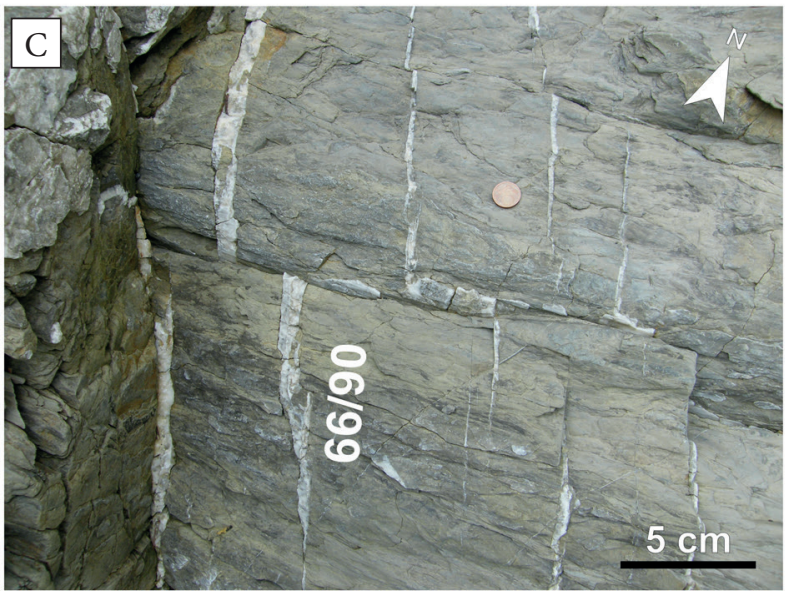

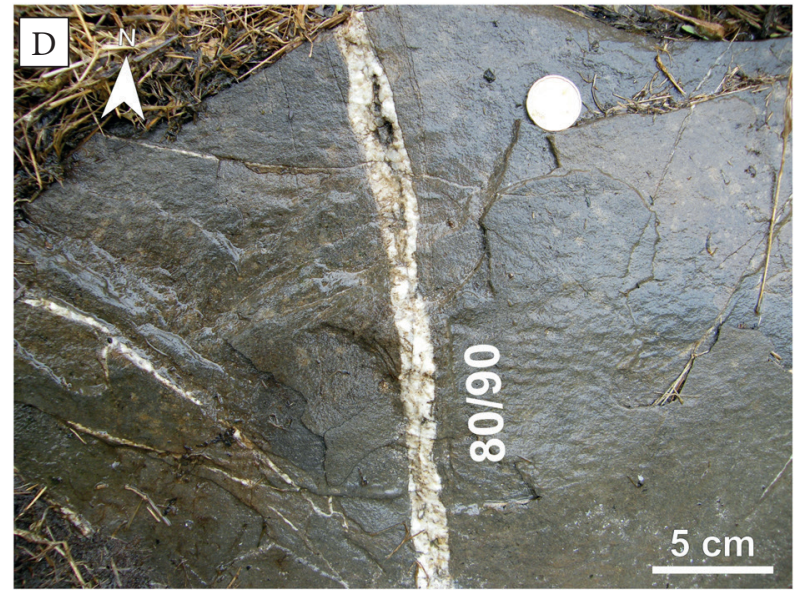

E transpression

simple shear

transtension
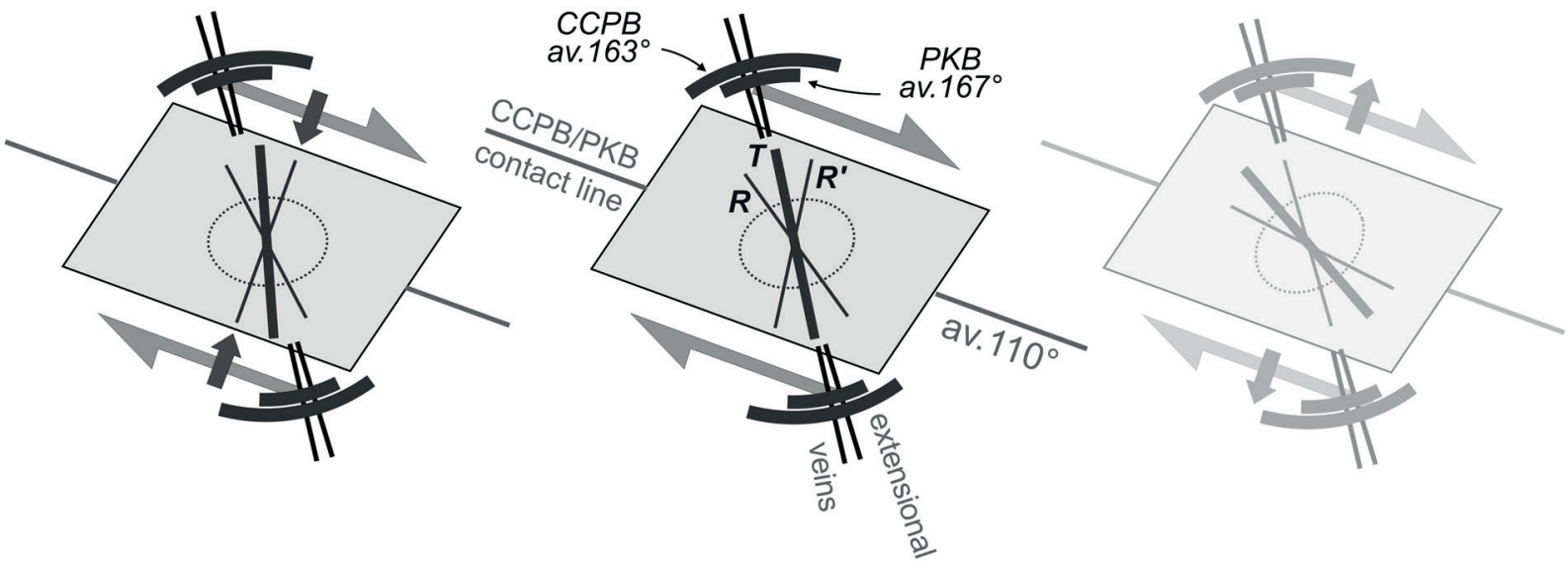

$\boldsymbol{T}$ - extension fractures

$\boldsymbol{R}$ - low-angle Riedel shears

$\boldsymbol{R}^{\prime}$ - high-angle Riedel shears

- instantaneous strain ellipse

Fig. 9. Calcite veins: $A), B$ ) orientation of veins compared to that of $P K B / C C P B$ contact line; $C), D$ ) examples from outcrops of the Upper Cretaceous marls of PKB in the Lipnik stream near Haligovce and from the Huty Fm. sandstones in the Lipnik stream at the eastern edge of Vel'ký Lipník village; E) scheme showing the relationships between a shear zone, Riedel shears and extension fractures (based on Ramsay 1967) at different strain conditions. The shearing direction is shown parallel to the average direction of the $P K B / C C P B$ contact line. Note that the observed calcite veins occupy the position of T-fractures developed under simple shear combined with a component of perpendicular shortening that is under transpression conditions. The angular relationships between hypothetical shears, extension fractures and shear zone extent are kept only for low strain values 


\section{Peri-Pieniny monocline}

In the eastern Podhale and Spiš areas (eastward of the Biały Dunajec Valley), c. 1.5-2 km south of the $\mathrm{CCPB} / \mathrm{PKB}$ contact line, the peri-Pieniny monocline zone is located (named the "Peri-Pieniny Flexure zone" by Pokropek 1960 and Mastella 1975) (Figs. 1C-E, 2). It is several hundred meters-wide, with its northern boundary marked by an abrupt increase of bedding dips. To the south of the peri-Pieniny monocline, the dips of flysch strata decrease abruptly to ca. $25^{\circ} \mathrm{S}$ within the northern part of the "zone of low dips" (Fig. 2) and gradually further decrease toward the Podhale Synclinorium axial zone.

The architecture of the peri-Pieniny monocline domain varies between different segments of the PS. In some segments it is represented by a longitudinal single monocline (see Fig. 2, cross section EF). Less often, in some sections, several smaller longitudinal monoclinic folds occur (see Fig. 2, cross section CD). The turbiditic beds within them are steeply inclined, up to a vertical or even overturned position. In these ССРВ segments, where the peri-Pieniny monocline passes across relatively more sandstone-rich complexes, dip-slip faults tend to occur instead of monoclines. In both cases, their southern sides are subsided. The total vertical displacement of the flysch strata on the peri-Pieniny monocline is estimated at approximately $800 \mathrm{~m}$ (Mastella et al. 1996). Its structural equivalent in the westernmost Podhale is perhaps the longitudinal strip of steepened flysch, sometimes occurring in an overturned position, and known as the "Pasieka fold" (Gołąb 1952).

The peri-Pieniny monocline most probably developed above a deep-rooted reverse fault being a part of a positive flower structure defining the present-day structural frame of the PKB (Plašienka et al. 1997, Plašienka 2011). Thus, this fault may be the southernmost border of the PKB. The very existence of the peri-Pieniny monocline seems to support the inference about the significant N-S tectonic shortening across the northern rim of the $\mathrm{CCPB}$ during the Early to Middle Miocene Outer Carpathian orogenic events and, together with the longitudinal strike-slip motion effects, corroborates the transpressional regime along the PKB boundaries.

\section{FIELD EXAMPLES}

Below, several field examples of the structural relationships reviewed above are demonstrated and explained in a sequence to be followed during the CETEG $16^{\text {th }}$ Meeting field session. The approximate location of the particular excursion stops at the background of the entire trip is presented in Figure 10.

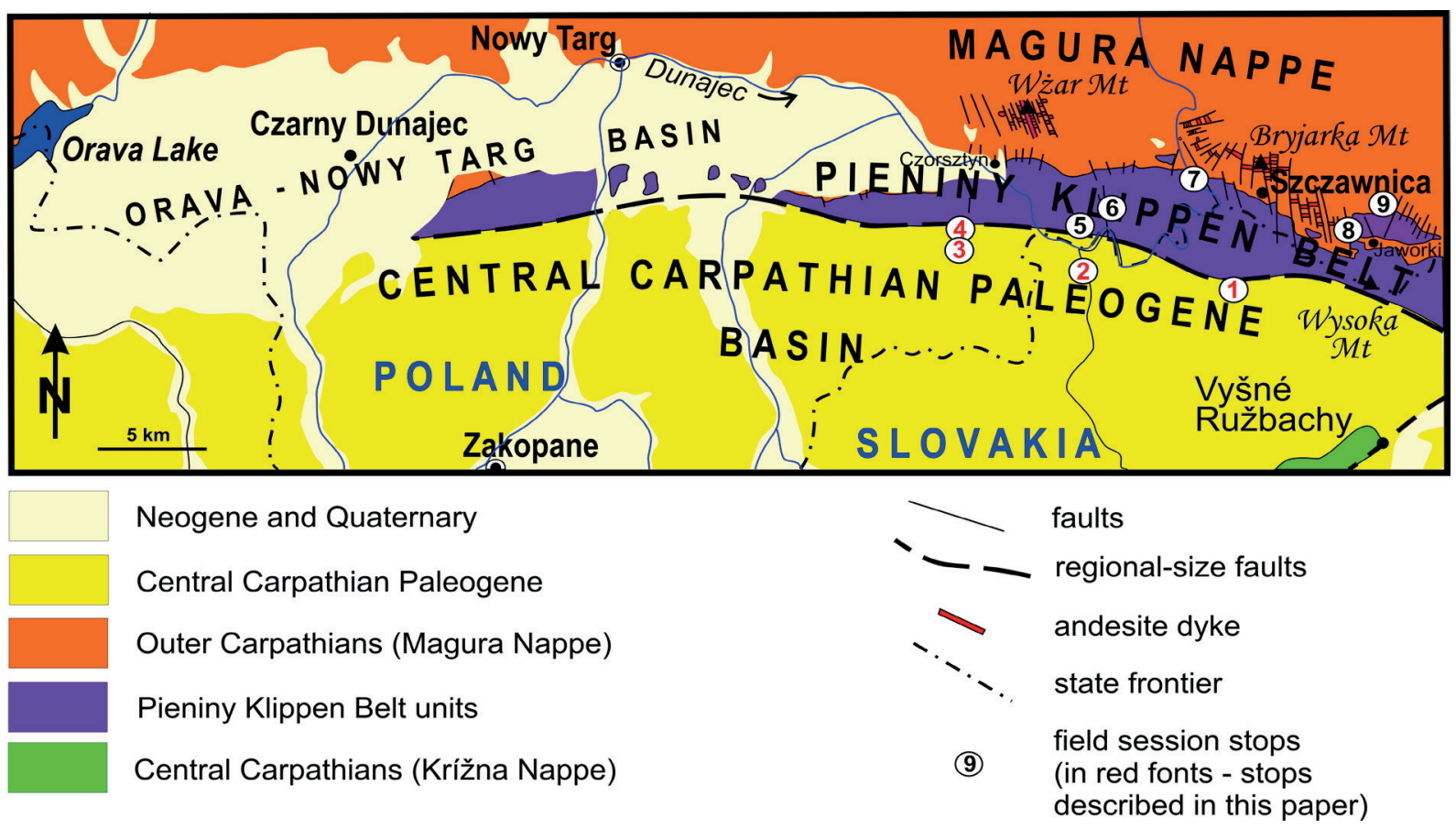

Fig. 10. Approximate location of field session stops on a generalized geological map showing the tectonic setting of the Pieniny Klippen Belt in Poland (based on Birkenmajer 1979 and Jurewicz 2005) 


\section{STOP 1}

Haligovce village, mouth of the Lorec stream into the Lipník stream

GPS location: N49.37994 ${ }^{\circ}$ E20.44142 ${ }^{\circ}$

Minor faults, shear zones and related structures in Upper Cretaceous rocks of the "klippen envelope" (Pieniny Klippen Belt)

Strongly deformed Upper Cretaceous rocks of the PKB "klippen envelope" (Púchov Fm.) (Fig. 7), represented by reddish- and grey-colored marls and marlstones, reveal numerous slickesided fault surfaces. The rock, within a c. $2 \mathrm{~m}$-wide zone bounded by nearly vertical faults, is intensely sheared, brecciated and affected by cataclastic flow (Fig. 7B). The shear zone contains lens-shaped bodies of the original, intact rock hosted in a cataclastic matrix, itself cut by small-scale curviplanar, anastomosing faults (high-strain bands) along which most of the displacement was concentrated. Such a deformation style is quite typical of the "klippen envelope" of the PKB.

Minor fault population occurs in the adjacent rock. It comprises faults of diverse orientation (Fig. 7A), in which WNW-ESE (to W-E)-trending strike-slip faults dominate. Such an orientation is concordant with that of the PKB in the vicinity. The faults are predominantly sinistral and their kinematics suggests they may represent an earlier sinistral event of the PKB evolution. The less numerous NE-SW and NNE-SSW-striking dextral faults seem to be second-order feather fractures or Riedel shears, associated with the already mentioned W-E-trending faults, parental with respect to them (high-angle R' and X shears, respectively).

\section{STOP 2}

Spišká Stará Ves village, Rieka stream GPS location: N49.38585 ${ }^{\circ} \mathrm{E} 20.36275^{\circ}$

Tectonic structures in Central Carpathian flysch, the peri-Pieniny monocline (I)

Tectonic deformation structures in flysch rocks of the Zakopane Beds (Huty Fm.) can be followed in the Rieka stream channel. The structures are located c. 1450-1500 m south of the inferred course of the $\mathrm{PKB} / \mathrm{CCPB}$ contact line underneath Holocene alluvial deposits of the Dunajec Valley (Fig. 1C). As it appears from geological maps (Kulka et al. 1985, Janočko et al. 2000) and DEM analysis, this locality occurs exactly at the extension of the deformed zone in the Kacwińska Rzeka stream described in Stop 3 (for location see Figure 10).

On the eastern side of the stream, tectonic deformation structures occur in a c. $15 \mathrm{~m}$-high and several tens of meters-wide zones (Fig. 11A). The southern edge of that zone is marked by a north-dipping reverse fault with strongly steepened beds in its footwall, near to the fault surface (Fig. 11A). Bedding dip values fall down abruptly southward to ca. $15-20^{\circ} \mathrm{S}$ at a distance of c. $4-5 \mathrm{~m}$ from the fault (Fig. 11B). In the upper part of the escarpment, a recumbent fold occurs within the fault's hanging wall (Fig. 11A).
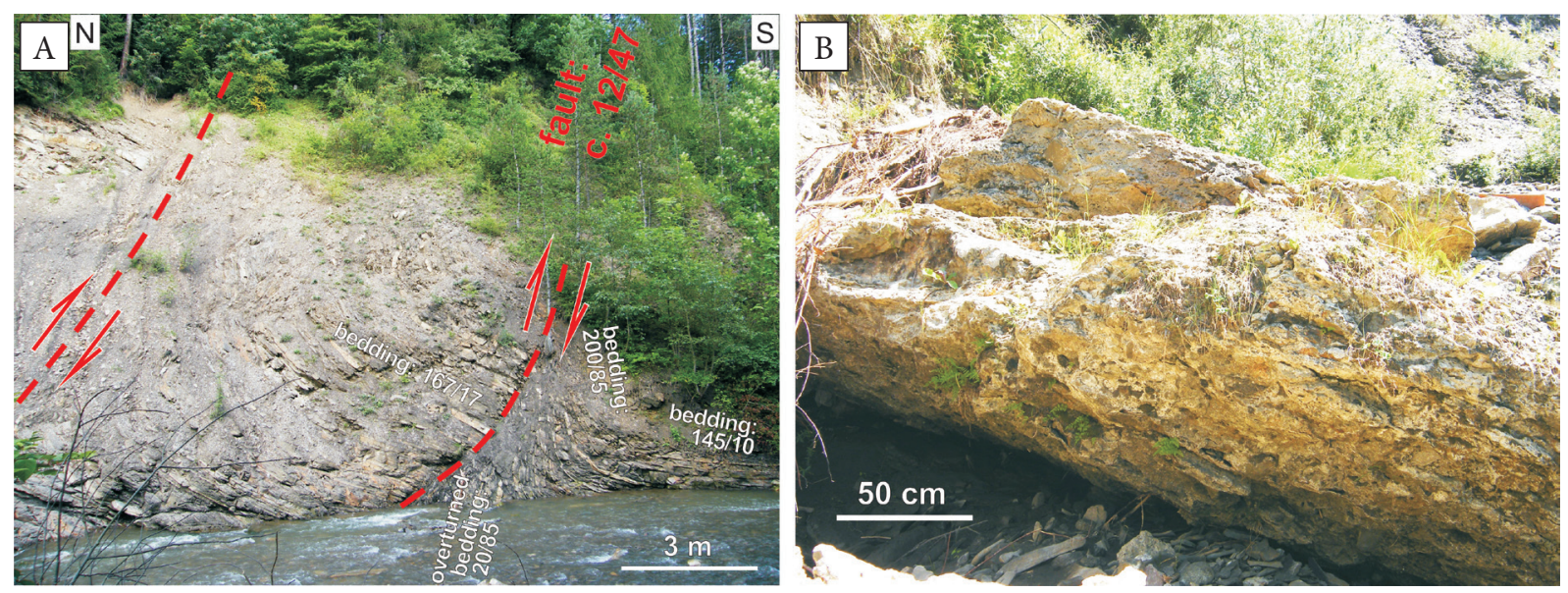

Fig. 11. Tectonic structures within the peri-Pieniny monocline (Rieka stream channel, Spišká Stará Ves village, Huty Fm.; field session stop 2): A) south-vergent reverse fault; fault-related drag of bedding (up to vertical or even overturned bedding attitude) in the footwall block is clear visible; B) block of massive calcareous tufa in the stream bed 
This fold is confined between two faults: the reverse one described above and its poorly visible neighbor with presumably analogous kinematic characteristics (Fig. 11A).

It should be mentioned that at the northern end of the outcrop, blocks of calcareous tufa detached from their original placement lie on the stream bed (Fig. 11B). Their size is up to c. $4 \mathrm{~m}$ in the longest dimension. They are massive rocks containing flysch sandstone clasts, in some cases representing pure porous tufas. Their occurrence in this location is most probably associated with deep-rooted faults of the peri-Pieniny monocline, the evidence in favor of which are the faults cropping out here (Fig. $11 \mathrm{~A}$ ). $\mathrm{CO}^{2}$-rich waters migrating upwards along these faults lixiviate calcium carbonate from the flysch rocks and underlying Mesozoic rocks of Krížna Nappe and PKB and precipitate it on the terrain surface as calcareous tufa. The occurrence of other numerous calcareous tufas in the neighborhood of the map-scale, as well as minor faults has been documented in the Podhale and Spiš area (e.g. Mastella et al. 1996, 2012, Kukulak 1999, Mastella 2008, Klimkiewicz et al. 2009, Głowacka 2010, Mastella \& Rybak-Ostrowska 2012).

\section{STOP 3}

\section{Kacwińska Rzeka stream, between Kacwin and Niedzica villages GPS location: N49.39583 ${ }^{\circ}$ E20.28861 ${ }^{\circ}$ Tectonic structures in Central Carpathian flysch, the peri-Pieniny monocline (II)}

At c. $1.7 \mathrm{~km}$ south of the $\mathrm{PKB} / \mathrm{CCPB}$ contact, the locality occurs in the middle of the peri-Pieniny monocline (Figs. 1E, 2). On this site, tectonic structures typical of its middle part are exposed in the flysch rocks of the Zakopane Beds (Huty Fm.).

On the western bank of the stream, in the c. 12 m-high escarpment, a south-vergent recumbent close fold is visible (Fig. 12A, B). Sandstone beds in the upper fold limb lie in an overturned position.
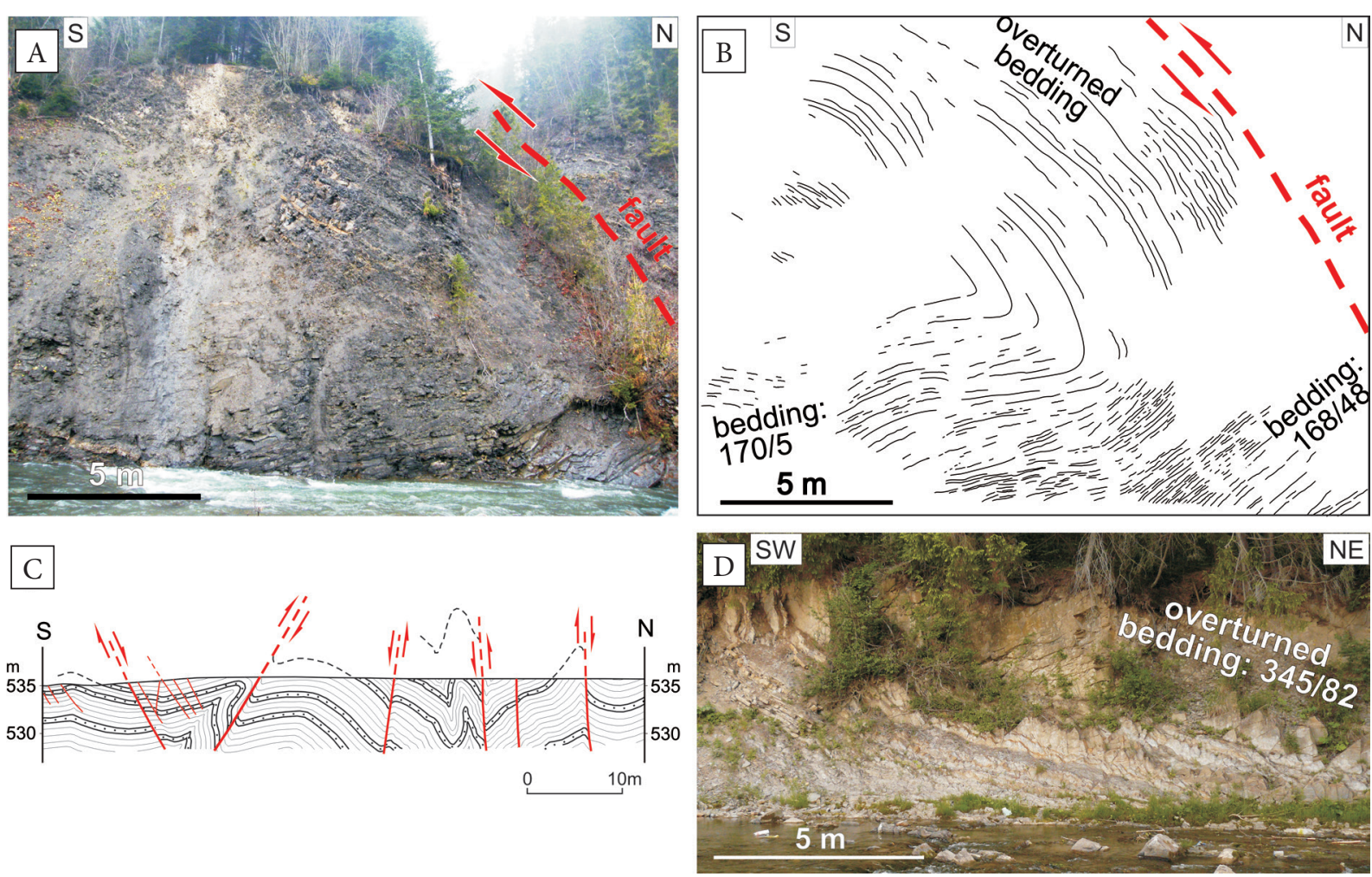

Fig. 12. Tectonic structures within the peri-Pieniny monocline (Kacwińska Rzeka stream channel, between Niedzica and Kacwin villages, Zakopane Beds): A), B) recumbent fold in the middle part of the monocline; C) detailed cross-section through a several dozen meters-wide sector of the peri-Pieniny monocline, southward from field session stop 3; D) vertical strata c. $200 \mathrm{~m}$ northward of field session stop 3 
The lower fold limb is flat-lying and an estimated W-E-trending fold axis is horizontal. This fold is probably related to a north-dipping reverse fault directly adjacent to the north (Fig. 12A, B) (traces of that fault seem to be reflected in the local topography as a weakly indented and c. $400 \mathrm{~m}$-long WNW-ESE-trending gorge). The fold must have developed simultaneously with the faulting as a consequence of fault drag, the effects of which are visible on a larger scale than that observed in the rest of the studied area.

Deformation effects of the flysch rocks visible at this locality continue into the southern part of the peri-Pieniny monocline (Fig. 12C). To the north of the present locality, the flysch strata show a deformation structures along a c. $250 \mathrm{~m}$-long stretch of the Kacwińska Rzeka stream channel. Besides the locally folded and faulted flysch strata, one can observe strata steepening up to the vertical position (Fig. 12D).

\section{STOP 4}

Niedzica village, Niedziczanka stream GPS location: between N49.40361 ${ }^{\circ}$ E20.29306 ${ }^{\circ}$ and $\mathrm{N} 49.40639^{\circ} \mathrm{E} 20.29194^{\circ}$

Tectonic structures

at the contact of the Pieniny Klippen Belt (PKB) and Central Carpathian Paleogene Basin (CCPB)

In the southern part of Niedzica village, in the Niedziczanka stream channel, a contact of Pieniny Klippen Belt with the Central Carpathian Palaeogene flysch rocks is exposed. The Cenomanian-Turonian red, light-grey and greenish Globotruncana marlstones of the Czorsztyn Succession (PKB) are juxtaposed there with fine- to medium-grained, and thin- to medium-bedded, less often thick-bedded sandstones intercalated with siltstones and claystones of the Lower Szaflary Beds (CCPB).

\section{Northern part of the outcrop}

The PKB/CCPB contact can be observed on the western bank of the stream. The contact itself is marked by a dozen meters-wide zone of strongly cataclastic and fractured rocks (Fig. 4C, D).

Strongly deformed flysch rocks of the Szaflary Beds on the southern side of the contact are cut by c. W-E trending steep to vertical faults with non-planar, uneven slip surfaces and their southern sides are consistently downthrown. These faults are traceable along the whole vertical extent of an escarpment. They commonly developed cataclastic zones, up to several dozen centimeters-wide. The flysch beds at the contact with those zones of cataclastic rocks are steeply inclined, vertical or overturned (Fig. 4C).

Numerous small faults cutting both the Upper Cretaceous rocks of the PKB and flysch strata of the CCPB can be seen there. They are mainly strike-slip faults, mostly of W-E (CCPB) and ENE-WSW (PKB) trends. The strike-slip faults are often accompanied by slickensides, drag folds and domino-like structures (Fig. 4A, B, E, F).

Seasonally, newly formed calcareous tufas related to fluid circulation along these faults can be observed during some years. They are weakly resistant to weathering and erosion but they can rebuild themselves during short periods of time (Fig. 4G).

\section{Southern part of the outcrop}

The upper part of the Lower Szaflary Beds crop out there. The bedding orientation of flysch rocks in this part of the outcrop is a little more stable than that in the rocks exposed at the contact with the PKB. The flysch beds are dipping south at $\mathrm{c}$. $40-70^{\circ}$, with their strikes at an angle of up to $45^{\circ}$ respective to the $\mathrm{PKB} / \mathrm{CCPB}$ contact line.

A rich inventory of mesoscopic faults can be studied at this site. The faults are well visible on the eastern side of the stream, along an escarpment. Most of them can be seen from the streambed level, whereas some others can be seen only from above, from the level of an adjacent meadow (Fig. 8B). These are mostly c. W-E-oriented strike-slip, dextral faults (Fig. 8B-D). As some of them cut and displace distinctive sandstone layers (Fig. 8C), an exact determination of the fault offset is possible (usually ranging from a dozen centimeters to a few meters). Combined observations of such markers, of slickensides and of fault-related drag folds, allow the recognition of the kinematic nature of the faults in question. A NE-SW-trending steep fault with both dextral and reverse motion indicators has been also recognized in this locality (Fig. 8A). Both those kinematics seem to be 
in line with the expected transpressional characteristic of deformation within this zone.

A single W-E trending, south dipping, low-angle thrust fault with a slip of up to a few meters (Fig. 8E, F) points to a possibility of N-S contraction during the late stage or even following the bedding tilting.

The author wishes to thank Pawet Aleksandrowski for his constructive criticism and Marta Tomaszczyk for her editorial help. This work was partly supported by the Institute of Geology, University of Warsaw (BST grant no. 166902).

\section{REFERENCES}

Aleksandrowski P., 1985. Tektonika regionu babiogórskiego: interferencja zachodnio- i wschodniokarpackich kierunków fałdowych. Annales Societatis Geologorum Poloniae, 55, 3-4, 375-422.

Aleksandrowski P., 1989. Geologia strukturalna płaszczowiny magurskiej w rejonie Babiej Góry. Studia Geologica Polonica, 96, Ossolineum, Wrocław.

Andrusov D., 1938. Geologický výskum vnitřního bradlového pásma v Západních Karpatech. III. Tektonika. Rozpravy Štátnego Geologickego Ústavu ÈSR, 9, 1-135.

Andrusov D., 1959. Geológia Československých Karpát II. SAV, Bratislava.

Andrusov D., 1965. Aperçu générale sur la géologie des Carpathes occidentales. Bulletin de la Société Géologique de France, 7, 1029-1062.

Bac-Moszaszwili M., 1993. Struktura zachodniego zakończenia masywu tatrzańskiego. Annales Societatis Geologorum Poloniae, 63, 1-3, 167-193.

Birkenmajer K., 1958. Mapa geologiczna pienińskiego pasa skałkowego, skala 1:10.000. Arkusz Dursztyn. Instytut Geologiczny, Warszawa.

Birkenmajer K., 1960a. Mapa geologiczna pienińskiego pasa skałkowego, skala 1:10.000. Arkusz Niedzica. Instytut Geologiczny, Warszawa.

Birkenmajer K., 1960b. Geology of the Pieniny Klippen Belt of Poland. Jahrbuch der Geologischen Bundesanstalt, 103, $1-36$.

Birkenmajer K., 1964. Mapa geologiczna pienińskiego pasa skatkowego, skala 1:10.000. Arkusz Trybsz. Instytut Geologiczny, Warszawa.

Birkenmajer K., 1977. Jurassic and Cretaceous lithostratigraphic units of the Pieniny Klippen Belt, Carpathians, Poland. Studia Geologica Polonica, 45, 1-158.

Birkenmajer K., 1979. Przewodnik geologiczny po pienińskim pasie skałkowym. Wydawnictwa Geologiczne, Warszawa.

Birkenmajer K., 1983. Uskoki przesuwcze w północnym obrzeżeniu pienińskiego pasa skałkowego w Polsce. Studia Geologica Polonica, 77, 89-112.

Birkenmajer K., 1985. Major strike-slip faults of the Pieniny Klippen Belt and the Tertiary rotation of the Carpathians. Publications of the Institute of Geophysics Polish Academy of Sciences, A-16, 175, 101-115.
Birkenmajer K., 1986. Stages of structural evolution of the Pieniny Klippen Belt, Carpathians. Studia Geologica Polonica, 88, 7-32.

Buslov M.M., Klerkx J., Abdrakhmatov K., Delvaux D., Batalev V.Yu., Kuchai O.A., Dehandschutter B. \& Muraliev A., 2003. Recent strike-slip deformation of the northern Tien Shan. [in:] Storti F., Holdsworth R.E. \& Salvini F. (eds.), Intraplate Strike-Slip Deformation Belts, Geological Society Special Publications, 210, Geological Society, London, 53-64.

Chmelík F., 1957. Zpráva o geologických výzkumech centrálne karpatského paleogénu v Šariši mezi. Šambronem a Sabinovem. Zprávy o geologických výzkumech, 81-88.

Csontos L., Nagymarosy A., Horváth F. \& Kováč M., 1992: Tertiary evolution of the Intracarpathian area: a model. Tectonophysics, 208, 1-3, 221-241.

Cunningham W.D., Windley B.F., Dorjnamjaa D., Badamgarov G. \& Saandar M., 1996. Late Cenozoic transpression in southwestern Mongolia and the Gobi Altai-Tien Shan connection. Earth and Planetary Sciences, $140,1-4,67-82$.

Cunningham W.D., Dijkstra A., Howard J., Quarles A. \& Badarch G., 2003. Active intraplate strike-slip faulting and transpressional uplift in the Mongolian Altai. [in:] Storti F., Holdsworth R.E. \& Salvini F. (eds.), Intraplate Strike-Slip Deformation Belts, Geological Society Special Publications, 210, Geological Society, London, 65-87.

Cunningham W.D. \& Mann P., 2007. Tectonics of strike-slip restraining and releasing bends. [in:] Cunningham W.D. \& Mann P. (eds.), Tectonics of Strike-Slip Restraining and Releasing Bends, Geological Society Special Publications, 290, Geological Society, London, 1-12.

Decker K. \& Peresson H., 1996. Tertiary kinematics in the Alpine-Carpathian-Pannonian system: links between thrusting, transform faulting and crustal extension. [in:] Wessely G. \& Liebl W. (eds.), Oil and gas in Alpidic thrust belts and basins of Central and Eastern Europe, Special Publications of the European Association of Geoscientists and Engineer, 5, Geological Society, London, 17-21.

Dewey J.F., Holdsworth R.E. \& Strachan R.A., 1998. Transpression and transtension zones. [in:] Holdsworth R.E, Strachan R.A. \& Dewey J.F. (eds.), Continental Transpressional and Transtensional Tectonics, Geological Society Special Publications, 135, Geological Society, London, 1-14.

Fleuty M.J., 1964. The description of folds. Proceedings of the Geologists' Association, 75, 461-492.

Fodor L., Csontos L., Bada G., Györfi I. \& Benkovics L., 1999. Tertiary tectonic evolution of the Pannonian Basin system and neighbouring orogens: a new synthesis of palaeostress data. Geological Society Special Publication, 156, London, Geological Society, 295-334.

Froitzheim N., Plašienka D. \& Schuster R., 2008. Alpine tectonics of the Alps and Western Carpathians. [in:] McCann T. (ed.), The Geology of Central Europe. 2. Mesozoic and Cenozoic, The Geological Society, London, 1141-1232.

Fusán O., Kodym O. Matějka A. \& Urbánek L., 1967. Geologická mapa ČSSR. 1:200 000 scale. Ústředni Ústav Geologický, Praha.

Garecka M., 2005. Calcareous nannoplankton from the Podhale Flysch (Oligocene-Miocene, Inner Carpathians, Poland). Studia Geologica Polonica, 124, 353-369. 
Gedl P., 2000. Biostratygrafia i paleośrodowisko paleogenu Podhala w świetle badań palinologicznych. Część I. Studia Geologica Polonica, 117, 69-154.

Głowacka A., 2010. Tektonika strefy osiowej synklinorium podhalańskiego na Spiszu (Słowacja). Archiwum Wydziału Geologii Uniwersytetu Warszawskiego [Ph.D. thesis].

Golonka J., Oszczypko N. \& Ślączka A., 2000. Late Carboniferous-Neogene geodynamic evolution and paleogeography of the circum-Carpathian region and adjacent areas. Annales Societatis Geologorum Poloniae, 70, 2, 107-136.

Golonka J. \& Krobicki M., 2001. Upwelling regime in the Carpathian Tethys: a Jurassic-Cretaceous palaeogeographic and palaeoclimatic perspective. Geological Quarterly, 45, 1, 15-32.

Golonka J. \& Krobicki M., 2004. Jurassic paleogeography of the Pieniny and Outer Carpathian basins. Rivista Italiana di Paleontologia e Stratigrafia, 110, 1, 5-14.

Gołąb J., 1952. Tektonika Podhala. Geologiczny Biuletyn Informacyjny, 1, 12-13.

Grabowski J., Krzemiński L., Nescieruk P. \& Starnawska E., 2006. Paleomagnetism of the teschenitic rocks (Lower Cretaceous) in the Outer Western Carpathians of Poland: constraints for the tectonic rotations in the Silesian unit. Geophysical Journal International, 166, 3, 1077-1094.

Gross P., Köhler E. \& Samuel O., 1984. Nové litostratigrafické členenie vnútrokarpatského paleogénu. Geologické Práce, $81,103-117$

Gross P., Filo I., Halouzka R., Haško J., Havrila M., Kováč P., Maglay J., Mello J. \& Nagy A., 1993. Geologická mapa južnej a východnej Oravy 1: 50 000. Ministerstvo Životného Prostredia - Geologický Ústav Dionýza Štúra, Bratislava.

Halicki B., 1963. Tektonika Podhala. Rocznik Polskiego Towarzystwa Geologicznego, 33, 349-362.

Hubbard M., 1999. Norumbega fault zone: Part of an orogen-parallel strike-slip system, northern Appalachians. [in:] Ludman A. \& West D.P., Jr., Norumbega Fault System of the Northern Appalachians, Special Papers of the Geological Society of America, 331, Geological Society of America, 155-165.

Janočko J., Gross P., Buček S., Karoli S., Žec B., Rakús M., Potfaj M. \& Halouzka R., 2000. Geologická mapa Spišskej Magury 1: 50 000. Ministerstvo Životného Prostredia Geologický Ústav Dionýza Štúra, Bratislava.

Jurewicz E., 1997. The contact between Pieniny Klippen Belt and Magura Unit (the Małe Pieniny Mts.). Geological Quarterly, 41, 3, 315-326.

Jurewicz E., 2005. Geodynamic evolution of the Tatra Mts. and the Pieniny Klippen Belt (Western Carpathians): problems and comments. Acta Geologica Polonica, 55, 3, 295-338.

Jurewicz E., 2018. The Šariš Transitional Zone, revealing interactions between Pieniny Klippen Belt, Outer Carpathians and European platform. Swiss Journal of Geosciences. DOI: https://doi.org/10.1007/s00015-017-0297-9.

Kázmér M., Dunkl I., Frisch W., Kuhlemann J. \& Ozsvárt P., 2003. The Palaeogene forearc basin of the Eastern Alps and Western Carpathians: subduction erosion and basin evolution. Journal of the Geological Society, 160, 3, 413-428.

Klimkiewicz D., Ludwiniak M., Mastella L., Cieszkowski M., Zuchiewicz W., Struska M. \& Tokarski A.K., 2009. Sesja terenowa A7, cz. 1. Elementy tektoniki fliszu podhalańskiego i Kotlina Orawsko-Nowotarska. [in:] Uchman A. \& Chowaniec J. (red.), Budowa geologiczna Tatr i Podhala ze szczególnym uwzględnieniem zjawisk geotermalnych na Podhalu, LXXIX Zjazd Naukowy PTG, Bukowina Tatrzańska, 27-30 września 2009 - materiały konferencyjne, PIG-PIB, Warszawa, 145-158.

Konon A., Ostrowski S., Rybak-Ostrowska B., Ludwiniak M., Śmigielski M., Wyglądała M., Uroda J., Kowalczyk S., Mieszkowski R. \& Kłopotowska A., 2016. Mnin restraining stepover - evidence of significant Cretaceous-Cenozoic dextral strike-slip faulting along the Teisseyre-Tornquist Zone? Acta Geologica Polonica, 66, 3, 429-449.

Kováč M., Nagymarosy A., Soták J. \& Šutovská K., 1993. Late Tertiary paleogeographic evolution of the Western Carpathians. Tectonophysics, 226, 1-4, 401-415.

Kováč P. \& Hók J., 1996. Tertiary development of the western part of Klippen Belt, Slovak Geological Magazine, 96, 2, 136-149.

Kováč M., Nagymarosy A., Oszczypko N., Csontos L., Ślączka A., Marunteanu M., Matenco L. \& Márton E., 1998. Palinspastic reconstruction of the Pannonian-Carpathian region during the Miocene. [in:] Rakús M (ed.), Geodynamic development of the Western Carpathians, Geological Survey of Slovak Republic, Bratislava, 189-217.

Kováč M., Plašienka D., Soták J., Vojtko R., Oszczypko N., Less Gy., Ćosović V., Fügenschuh B. \& Králiková S., 2016. Paleogene palaeogeography and basin evolution of the Western Carpathians, Northern Pannonian domain and adjoining areas. Global and Planetary Change, 140, 9-27.

Kruczyk J., Kądziałko-Hofmokl M., Lefeld J., Pagač P. \& Túnyi I., 1992. Paleomagnetism of Jurassic sediments as evidence for oroclinal bending of the Inner West Carpathians. Tectonophysics, 206, 3-4, 315-324.

Kukulak J., 1999. Orientacja spękań i uskoków w południowo-wschodniej części zapadliska orawskiego. Przegląd Geologiczny, 47, 11, 1021-1026.

Kulka A., Rączkowski W., Żytko K., Gucik S. \& Paul Z., 1985. Szczegółowa Mapa Geologiczna Polski 1:50 000. Arkusz Szczawnica - Krościenko. Wydawnictwa Geologiczne, Warszawa.

Lacquement F., Averbuch O., Mansy J.-L., Szaniawski R. \& Lewandowski M., 2005. Transpressional deformations at lateral boundaries of propagating thrust-sheets: The example of the Meuse Valley Recess within the Ardennes Variscan fold-and-thrust belt (N France-S Belgium). Journal of Structural Geology, 27, 10, 1788-1802.

Ludwiniak M., 2006. Geometria i geneza sieci spękań ciosowych we fliszu zachodniego Podhala. Archiwum Wydziału Geologii Uniwersytetu Warszawskiego [Ph.D. thesis].

Ludwiniak M., 2010. Multi-stage development of the joint network in the flysch rocks of western Podhale (Inner Western Carpathians, Poland). Acta Geologica Polonica, $60,2,283-316$.

Ludwiniak M. \& Rybak-Ostrowska B., 2010. Jelešňa fault zone (Central Carpathian Palaeogene Basin, SE Orava, Slovakia) - preliminary results of studies. [in:] Ludwiniak M., Konon A. \& Żylińska A. (red.), $8^{\text {th }}$ Meeting of the Central European Tectonic Studies Group (CETeG), Conference Proceedings, 22-25 April 2010, Machocice Kapitulne, Poland. Conference Proceedings, University of 
Warsaw, Polish Geological Institute - National Research Institute, Warsaw, 91-93.

Ludwiniak M., Klimkiewicz D. \& Mastella L., 2009. Tektonika Podhala. [in:] Uchman A. \& Chowaniec J. (red.), Budowa geologiczna Tatr i Podhala ze szczególnym uwzględnieniem zjawisk geotermalnych na Podhalu, LXXIX Zjazd Naukowy PTG, Bukowina Tatrzańska, 27-30 września 2009 - materialy konferencyjne, PIG-PIB, Warszawa, 27-30.

Marín-Lechado C., Galindo-Zaldívar J., Rodríguez-Fernández L.R. \& González-Lodeiro F., 2004. Faulted hybrid joints: an example from the Campo de Dalias (Betic Cordilleras, Spain). Journal of Structural Geology, 26, 11, 2025-2037.

Marko F., 2015. Do we need the orogeny-parallel dextral strike-slips during the Miocene tectonic evolution of the Western Carpathians?, Mineralia Slovaca, 47, 1, 91-96.

Márton E. \& Fodor L., 1995. Combination of paleomagnetic and stress data - a case study from North Hungary. Tectonophysics, 242, 1-2, 99-114.

Márton E., Grabowski J., Plašienka D., Túnyi I., Krobicki M., Haas J. \& Pethe M., 2013. New paleomagnetic results from the Upper Cretaceous red marls of the Pieniny Klippen Belt, Western Carpathians: Evidence for general CCW rotation and implications for the origin of the structural arc formation. Tectonophysics, 592, 1-13.

Márton E., Grabowski J., Tokarski A.K. \& Túnyi I., 2016. Palaeomagnetic results from the fold and thrust belt of the Western Carpathians: An overview. Geological Society Special Publication, 425, 1, Geological Society, London, 7-36.

Marschalko R., 1968. Facies distributions, paleocurrents and paleotectonics of the Paleogene Flysch of Central West-Carpathians. Geologický Zborník - Geologica Carpathica, 19, 1, 69-94.

Martínez-Díaz J.J., 2002. Stress field variation related to fault interaction in a reverse oblique-slip fault: The $\mathrm{Al}$ hama de Murcia fault, Betic Cordillera, Spain. Tectonophysics, 356, 4, 291-305.

Mastella L., 1972. Tektonika fliszu wschodniego Podhala. Archiwum Wydziału Geologii Uniwersytetu Warszawskiego [Ph.D. thesis].

Mastella L., 1975. Tektonika fliszu we wschodniej części Podhala. Annales Societatis Geologorum Poloniae, 45, 3-4, 361-401.

Mastella L., 2008. Tektoniczne uwarunkowania występowania martwic wapiennych we fliszu podhalańskim. [in:] Gaździcka E. (red.), Tatrzańskie mapy geologiczne: materiały konferencyjne, Zakopane, 27-29 maja 2008, Państwowy Instytut Geologiczny, Warszawa, 31-35.

Mastella L. \& Rybak-Ostrowska B., 2012. Tectonic control of tufa occurrences in the Podhale Synclinorium (Central Western Carpathians, southern Poland). Geological Quarterly, 56, 4, 733-744.

Mastella L., Ozimkowski W. \& Szczęsny R., 1988. Tektonika północno-zachodniej części fliszu podhalańskiego. Przegląd Geologiczny, 36, 10, 566-572.

Mastella L., Konon A. \& Mardal T., 1996. Tektonika fliszu podhalańskiego w dolinie Białki. Przeglad Geologiczny, $44,12,1189-1194$.

Mastella L., Ludwiniak M. \& Klimkiewicz D., 2012. Budowa geologiczna doliny Białego Dunajca. Przegląd Geologicz$n y, 60,9,496-505$.
Molnar P., 1992. Brace-Goetze strength profiles, the partitioning of strike-slip and thrust faulting at zones of oblique convergence and the stress-heat flow paradox of the San Andreas Fault. [in:] Evans B. \& Wong T.-F. (eds.), Fault mechanics and transport properties in rocks, Academic Press, London, 359-435.

Molnar P. \& Tapponier P., 1975. Cenozoic tectonics of Asia: effects of a continental collision. Science, 189, 4201, 419426.

Moody J.D. \& Hill M.J., 1956. Wrench-fault tectonics. Geological Society of America Bulletin, 67, 1207-1246.

Morley C.K., Kongwung B., Julapour A.A., Abdolghafourian M., Hajian M., Waples D., Warren J., Otterdoom H., Srisuriyon K. \& Kazemi H., 2009. Structural development of a major late Cenozoic basin and transpressional belt in central Iran: the Central Basin in the Qom-Saveh area. Geosphere, 5, 4, 1-38.

Nemčok J., 1990. Geologická mapa Pienin, Čergova, L’ubovnianskej a Ondavskej vrchoviny. Slovenský Geologický Úrad - Geologický Ústav Dionýza Štúra, Bratislava.

Olszewska B. \& Wieczorek J., 1998. The Paleogene of the Podhale Basin (Polish Inner Carpathians) - micropaleontological perspective. Przegląd Geologiczny, 46, 8/2, 721-728.

Oszczypko N. \& Ślączka A., 1989. The evolution of the Miocene Basin in the Polish Outer Carpathians and their foreland. Geologica Carpathica, 40, 1, 23-36.

Picha F., 1996. Exploring for hydrocarbons under thrust belts - A challenging new frontier in the Carpathians and elsewhere. American Association of Petroleum Geologists Bulletin, 80, 10, 1547-1564.

Picha F.J., Stráník Z. \& Krejčí O., 2006. Geology and hydrocarbon resources of the Outer Western Carpathians and their foreland, Czech Republic. [in:] Golonka J. \& Picha F.J. (eds.), The Carpathians and their foreland: Geology and hydrocarbon resources, American Association of Petroleum Geologists Memoir, 84, AAPG, 49-175.

Plašienka D., 2011. The Pieniny Klippen Belt - structure, evolution and position in the Carpathian tectonic framework. Geologické Výzkumy na Moravé a ve Slezsku, $1,39-44$.

Plašienka D., 2012. Early stages of structural evolution of the Carpathian Klippen Belt (Slovakian Pieniny sector). Mineralia Slovaca, 44, 1, 1-16.

Plašienka D. \& Mikuš V., 2010. Geological settings of the Pieniny and Šariš sectors of the Klippen Belt between Litmanová and Drienica villages in eastern Slovakia. Mineralia Slovaca, 42, 2, 155-178.

Plašienka D. \& Soták J., 1999. Stop 6. Kamenica. Antiformal stacking of Šambron periklippen zone in response to transpression and backthrusting. [in:] Decker K., Marko F., Soták J. \& Świerczewska A. (eds.), $5^{\text {th }}$ Carpathian Tectonic Workshop, Poprad - Szymbark, 5-9 June 1999, Kraków Research Centre, Institute of Geological Sciences, Polish Academy of Sciences, Geological Institute, Slovak Academy of Sciences, Faculty of Sciences, Comenius University, Institute of Geology, Vienna University, Carpathian Branch, Polish Geological Survey, 8-10.

Plašienka D. \& Soták J., 2015. Evolution of Late CretaceousPalaeogene synorogenic basins in the Pieniny Klippen Belt and adjacent zones (Western Carpathians, Slovakia): tectonic controls over a growing orogenic wedge. Annales Societatis Geologorum Poloniae, 85, 1, 43-76. 
Plašienka D., Grecula P., Putiš M., Kováč M. \& Hovorka D., 1997. Evolution and structure of the Western Carpathians: an overview. Mineralia Slovaca. [in:] Grecula P., Putiš M. \& Hovorka D (eds.), Geological evolution of the Western Carpathians, Mineralia Slovaca Corp. - Geocomplex, 1-24.

Plašienka D., Soták J. \& Prokešová R., 1998. Structural profiles across the Šambron - Kamenica Periklippen Zone of the Central Carpathian Paleogene Basin in NE Slovakia. Mineralia Slovaca, 29, 3, 173-184.

Plašienka D., Vozár J. \& Bielik M., 2008. The Pieniny Klippen Belt at the depth - rooted, or unrooted. [in:] Németh Z. \& Plašienka D. (eds.), Proceedings and Excursion Guide, SlovTec 08: $6^{\text {th }}$ Meeting of the Central European Tectonic Studies Group (CETeG) \& $13^{\text {th }}$ Meeting of the Czech Tectonic Studies Group (ČTS), Upohlav, Slovakia 23-26 April 2008, State Geological Institute of Dionyz Štur, Bratislava, 104-108.

Plašienka D., Józsa Š., Gedl P. \& Madzin J., 2013. Fault contact of the Pieniny Klippen Belt with the Central Carpathian Paleogene Basin (Western Carpathians): new data from a unique temporary exposure in Lutina village (Eastern Slovakia). Geologica Carpathica, 64, 2, 165-168.

Pokropek W., 1960. Pótnocna strefa tektoniczna fliszu Podhala. Archiwum Wydziału Geologii Uniwersytetu Warszawskiego [M.Sc. thesis].

Pomianowski P., 1988. Anomalie termiczne nad strefą kontaktową pienińskiego pasa skałkowego $\mathrm{z}$ fliszem podhalańskim. Przeglad Geologiczny, 35, 2, 94-97.

Pospišil L. \& Filo M., 1982. Niektoré problémy a výsledky interpretácie tiažových anomálií v širšom okoli humenskej štruktúry. Mineralia Slovaca, 14, 4, 343-353.

Qu Guosheng \& Zhang Jinjiang, 1994. Oblique thrust system in the Altay orogen. China. Journal of Southeast Asian Earth Sciences, 9, 3, 277-287.

Ramsay J.G., 1967. Folding and Fracturing of Rocks. McGraw-Hill, New York.

Ratschbacher L., Frisch W., Linzer H.-G., Sperner B., Meschede M., Decker K., Nemčok M., Nemčok J. \& Grygar R., 1993. The Pieniny Klippen Belt in the Western Carpathians of northeastern Slovakia: structural evidence for transpression. Tectonophysics, 226, 1-4, 471-483.

Roniewicz P., 1969. Sedymentacja eocenu numulitowego Tatr. Acta Geologica Polonica, 19, 3, 503-608.

Royden L.H., 1988. Late Cenozoic tectonics of the Pannonian Basin system. [in:] Royden L.H. \& Horvath F. (eds.), The Pannonian Basin. A Study in Basin Evolution, American Association of Petroleum Geologists Memoirs, 45, AAPG, 27-48.

Royden L.H., Horváth F. \& Burchfiel B.C., 1982. Transform faulting, extension, and subduction in the Carpathian Pannonian region. Geological Society of America Bulletin, 93, 8, 717-725.
Royden L., Horváth F. \& Rumpler J., 1983. Evolution of the Pannonian basin system. 1. Tectonics. Tectonics, 2, 1, 63-90.

Soták J. \& Bebej J., 1996. Serpentinitic sandstones from the Šambron-Kamenica zone in eastern Slovakia: evidence of deposition in a tertiary collisional belt. Geologica Carpathica, 47, 4, 227-238.

Soták J., Pereszlenyi M., Marschalko R., Milicka J. \& Starek D., 2001. Sedimentology and hydrocarbon habitat of the submarine-fan deposits of the Central Carpathian Paleogene Basin (NE Slovakia). Marine and Petroleum Geology, 18, 87-114.

Storti F., Holdsworth R.E. \& Salvini F., 2003. Intraplate StrikeSlip Deformation Belts. [in:] Storti F., Holdsworth R.E. \& Salvini F. (eds.), Intraplate Strike-Slip Deformation Belts, Geological Society Special Publications, 210, Geological Society, London, 1-14.

Sylvester A.G., 1988. Strike-slip faults. Geological Society of America Bulletin, 100, 11, 1666-1703.

Şengör A.M.C., 1990. Plate tectonics and orogenic research after 25 years: a Tethyan perspective. Earth Science Reviews, 27, 1-2, 1-201.

Ślączka A., 1996a. Oil and gas in the northern Carpathians. [in:] Wessely G. \& Liebl W. (eds.), Oil and gas in Alpidic thrust-belts and basins of Central and Eastern Europe, Special Publications of the European Association of Geoscientists and Engineers, 5, Geological Society, London, 187-195.

Ślączka A., 1996b. Oil and gas in the Ukrainian part of the Carpathians and their foredeep. [in:] Wessely G. \& Liebl W. (eds.), Oil and gas in Alpidic thrust-belts and basins of Central and Eastern Europe, Special Publications of the European Association of Geoscientists and Engineers, 5, Geological Society, London, 17-21.

Śmigielski M., Koprianiuk M. \& Konon A., 2011. Determination of fault displacement vector parameters based on strike separation. Przeglad Geologiczny, 59, 1, 74-81.

Uhlig V., 1897. Die Geologie des Tatragebirges, I. Denkschriften Mathematisch-Naturwissenschaftlichen Classe. Academie der Wissenschaften, Wien, 64, 643-684.

Uhlig V., 1903. Bau und Bild der Karpathen. Tempsky, Wien.

Watycha L., 1968. Preliminary estimation of conditions and possibilities of formation of oil deposits in the eastern part of the Podhale flysch. Geological Quarterly, 12, 4, 898-915.

Woodcock N.H. \& Schubert C., 1994. Continental strike slip tectonics. [in:] Hancock P.L. (ed.), Continental Deformation, Pergamon Press, Oxford, 251-263.

Zoetemeijer R., Tomek Č. \& Cloetingh S., 1999. Flexural expression of European continental lithosphere under the western outer Carpathians. Tectonics, 18, 5, 843-861. 